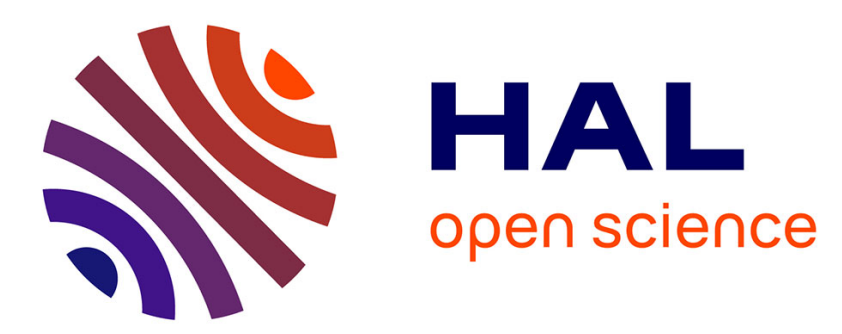

\title{
Cutmark data and their implications for the planning depth of Late Pleistocene societies
}

Marie-Cécile Soulier, Eugène Morin

\section{To cite this version:}

Marie-Cécile Soulier, Eugène Morin. Cutmark data and their implications for the planning depth of Late Pleistocene societies. Journal of Human Evolution, 2016, 97, pp.37-57. 10.1016/j.jhevol.2016.05.006 . hal-01842551

\section{HAL Id: hal-01842551 https://hal.science/hal-01842551}

Submitted on 25 Mar 2021

HAL is a multi-disciplinary open access archive for the deposit and dissemination of scientific research documents, whether they are published or not. The documents may come from teaching and research institutions in France or abroad, or from public or private research centers.
L'archive ouverte pluridisciplinaire HAL, est destinée au dépôt et à la diffusion de documents scientifiques de niveau recherche, publiés ou non, émanant des établissements d'enseignement et de recherche français ou étrangers, des laboratoires publics ou privés. 


\title{
Cutmark data and their implications for the planning depth of Late Pleistocene societies
}

\author{
Marie-Cécile Soulier ${ }^{\mathrm{a},}$ and Eugène Morin ${ }^{\mathrm{b}, \mathrm{c}}$
}

${ }^{a}$ CNRS UMR 5608 TRACES, Univ. Toulouse Jean-Jaurès, Maison de la Recherche, 5 allées A. Machado, 31058 Toulouse Cedex 9, France

b Trent University, Department of Anthropology, DNA Bldg Block C, 2140 East Bank Drive, Peterborough, Ontario, Canada K9J 7B8

' CNRS UMR 5199 PACEA, Univ. Bordeaux, bâtiment B8, allée Geoffroy St-Hilaire, CS 50023, 33615 Pessac Cedex, France

\section{*Corresponding author}

E-mail address: mariecsoulier@gmail.com (M.-C. Soulier)

Keywords: Zooarchaeology, Paleolithic, Carcass processing, Subsistence, Meat drying, Butchery

\begin{abstract}
Cutmarks provide empirical evidence for the exploitation of animal resources by past human groups. Their study may contribute substantially to our knowledge of economic behavior, including the procurement of prey and the analysis of butchery sequences. Butchering practices can be investigated using cutmark illustrations recorded on bone templates. In this paper, quantitative data on cutmarks were derived from published and unpublished cutmark drawings for 27 French assemblages dated between the late Middle Paleolithic and the final Upper Paleolithic. The analysis of cutmark data on meaty long bones (humerus, radio-ulna, femur, tibia) highlights strong variations in cutmark length and orientation in the sample that potentially reflect significant shifts in meat processing strategies during the Late Pleistocene. The present study shows that long longitudinal cutmarks are considerably more frequent during the Late Glacial Maximum than in the early Upper Paleolithic. Although the number of studies is small, actualistic data generated in controlled settings indicate that long longitudinal cutmarks are commonly produced during filleting, an activity closely associated with meat preservation, as is the case with drying and smoking. Because they provide information on possible changes in the capacity for anticipation, these results have potentially important implications for the logistical and economic organization of Paleolithic hominins.
\end{abstract}

\section{Introduction}


Numerous studies have highlighted the significance of planning depth to the evolution of complex cognition and the emergence of linguistic abilities (e.g., Binford, 1978; Whallon, 1989; Botha, 2008; Bickerton, 2009; Roebroeks and Verpoorte, 2009). However, studying planning depth in the archaeological record poses significant challenges because archaeological signatures are equivocal. Extending the preservation of meat through drying, smoking, and other processes is of considerable theoretical relevance given that these activities entail anticipation of transport costs (through a reduction in meat weight and volume) and/or dietary needs at time scales varying between a few hours to months. Therefore, documenting how activities focused on meat preservation developed over time may yield critical insights into the biological evolution and social organization of past hominins. We focus here on cutmark data, as these constitute one productive window enabling the study of the emergence of meat preservation in the Plio-Pleistocene.

Cutmarks have received sustained attention in the last forty years because they provide valuable information on agency and foraging strategies (Binford, 1981; Lyman, 1994). An obvious starting point in cutmark research has been the problem of identification, with several studies addressing the issue of how cutmarks can be distinguished from superficial scratches caused by friction with sedimentary particles. Thanks to experimental replications and analyses of controlled data (e.g., studies of ungulate trampling marks, and reports investigating marks observed at contemporary human campsites), several criteria have been shown to be diagnostic of cutmark production (e.g., Gifford-Gonzalez and Behrensmeyer, 1977; Potts and Shipman, 1981; Courtin and Villa, 1982; Shipman and Rose, 1983, 1984; Andrews and Cook, 1985; Behrensmeyer et al., 1986; Haynes, 1986; Olsen and Shipman, 1988; Andrews, 1995; Domínguez-Rodrigo et al., 2009; Thiébaut et al., 2010). Further experiments have emphasized variation in cutmarks, for instance by indicating that their frequency and morphology is influenced by the class of raw material and the aspect of the tool (e.g., with retouched edges or not) used during butchery (e.g., Walker and Long, 1977; Walker, 1978; Potts and Shipman, 1981; Olsen, 1988; Greenfield, 1999, 2006; Dewbury and Russel, 2007; de Juana et al., 2010).

More contentious has been the interpretation of patterns in cutmark location and orientation. Although the analysis of this type of data is not new (e.g., Henri-Martin, 1907), the ethnoarchaeological study conducted by Binford (1981) among the Nunamiut of Alaska has been particularly influential, as it provided cutmark criteria permitting the recognition of specific processing goals in a faunal assemblage. These data launched fertile discussions on the timing of access to the carcasses of large ungulates in the Paleolithic record (e.g., Binford, 1984, 1988; Bunn and Kroll, 1986; Marshall, 1986; Shipman, 1988, 1986; Lupo, 1994; Domínguez-Rodrigo, 1997; Lupo and O'Connell, 2002). Studies have since examined the behavioral context of cutmark production for a wide range of species, generally from an ethnoarchaeological (e.g., Binford, 1981; Gifford-Gonzalez, 1989; Lupo, 1994; Nilssen, 2000; Abe, 2005; Costamagno and David, 2009) or experimental standpoint (e.g., Jones, 1980; Bez, 1995; Laroulandie, 2001; Egeland, 2003; Domínguez-Rodrigo and Barba, 2005; Vigne, 2005; Padilla Cano, 2008; Lloveras et al., 2009; Mallye, 2011; Thiébaut et al., 2011; Val and Mallye, 2011; DomínguezRodrigo et al., 2012; Galán and Domínguez-Rodrigo, 2013; Egeland et al., 2014). Although the above studies have concluded that certain cutmarks are ubiquitous and non-diagnostic, a substantial number of cutmark types are arguably closely linked to specific butchering activities.

The behavioral implications of changes in cutmark distribution and orientation patterns have been investigated in an original analysis of the Southwest Asian Pleistocene record (Stiner et al., 2009). The abundant and frequently randomly-oriented cutmarks observed on ungulate long bones in the Lower Palaeolithic from Qesem Cave led Stiner et al. (2009) to hypothesize that this pattern may be indicative of the processing activities of a relatively large number of individuals involved in meat removal, whereas those of the Middle and Late Pleistocene samples would reflect more focused tasks performed by one or a few individuals. However, wellcontrolled datasets have shown that the relationship between a given pattern of orientation and the number of individuals involved in meat removal is difficult to interpret because several factors (e.g., variation in skill and experience, whether a carcass is processed all at once or over several episodes) may result in randomly oriented cutmarks (Speth, 2012; Egeland et al., 2014). In southwest France, a study of several ungulate assemblages found in Upper Paleolithic contexts has also explored long-term shifts in cutmark patterns (Soulier, 2013). This last study found provisional support for change in cutmark orientation over time. However, a lack of quantitative data precluded a fuller appreciation of the economic and social ramifications of the suspected pattern. Thus, a renewed investigation of the significance of cutmark variation may shed further light on the potential implications of the diachronic patterns uncovered in these studies. 
In this paper, we first examine the context of production of various types of cutmarks in controlled settings to assess patterns of cutmark variation in distinct carcass processing activities. Cutmark quantitative measurements from actualistic butcheries are then compared with those from a large set of French Paleolithic assemblages. This dataset provides a framework for exploring changing attitudes toward meat exploitation during the Late Pleistocene.

\section{Cutmark variation in actualistic contexts}

Numerous actualistic studies have analyzed cutmark production during butchery activities. The information presented here draws on the most detailed and best illustrated of these studies (Binford, 1981; Bez, 1995; Nilssen, 2000; Abe, 2005; Vigne, 2005; Costamagno and David, 2009; Thiébaut et al., 2011; Galán and Domínguez-Rodrigo, 2013). The information discussed below is limited to a general description of cutmarks examined according to five main classes of processing activities: skinning, sinew removal, dismembering, defleshing, and periosteum removal. This survey of the actualistic record is critical for our purpose, as it provides a control against which the archaeological samples can be compared. Note that, in this survey, the emphasis is put on the behavioral contexts in which longitudinal cutmarks are made, as these may inform the analysis of a hypothesized increased representation of longitudinal cut marks during the Upper Paleolithic (Soulier, 2013). Because our analysis focuses exclusively on ungulates, other taxa are not considered here.

According to actualistic studies, skinning cutmarks occur on bones where the soft tissues are thinly distributed or where the skin is in direct contact with the bone. As a result, skinning cutmarks typically prevail on the skull, mandible, metapodials, carpals, tarsals, phalanges, vestigial phalanges, and caudal vertebrae (e.g., Binford, 1981; Bez, 1995; Nilssen, 2000; Costamagno and David, 2009; Thiébaut et al., 2011). Longitudinal cutmarks resulting from skinning are sometimes present on the distal shaft of the radio-ulna and tibia (Nilssen, 2000; Thiébaut et al., 2011). However, experimental and ethnoarchaeological data suggest that these cutmarks are uncommon.

Dismemberment cutmarks are, by definition, confined in their distribution to the articulations and immediately adjacent bone regions (e.g., Binford, 1981; Bez, 1995; Nilssen, 2000; Vigne, 2005; Costamagno and David, 2009; Thiébaut et al., 2011; Galán and Domínguez-Rodrigo, 2013). These cutmarks are generally deep and short (Binford, 1981; Bez, 1995; Nilssen, 2000; Thiébaut et al., 2011). Contrary to early claims (Binford, 1981), dismemberment cutmarks are not always transverse. Rather, their orientation appears to be directly influenced by the position adopted by the butcher when holding the skeletal elements during the dismemberment process (Bez, 1995; Nilssen, 2000; Thiébaut et al., 2011). Because defleshing requires sectioning tendons and ligaments located on the shaft extremities, some cutmarks initially considered diagnostic of disarticulation are now known to overlap with those resulting from meat removal (Nilssen, 2000; Thiébaut et al., 2011; Costamagno, 2012; Galán and Domínguez-Rodrigo, 2013).

Sinews are present on most skeletal elements. Nonetheless, in a majority of cases, they are short and arguably of limited use. In actualistic contexts, the long sinews and tendons near the spine and those in the distal limb elements are preferentially selected, generating short, transverse, and deep cutmarks on metapodials and phalanges (Costamagno and David, 2009; Thiébaut et al., 2011). Some experiments have reported the production of long longitudinal cutmarks in the grooves of metapodials, and less frequently, on the distal shaft of the radioulna and tibia, during sinew extraction (Vigne, 2005; Thiébaut et al., 2011; Costamagno 2012).

Removing the periosteum using a cutting tool may generate longitudinal cutmarks, as reported by Costamagno and David (2009) in their study of reindeer herders in Russia. However, the use of an axe during marrow cracking, combined with evidence suggesting that longitudinal marks were produced for 'cultural' as opposed to strictly 'functional' reasons (Costamagno, comm. pers., 2014), raise some concern about the general significance of these observations for Paleolithic contexts. Nonetheless, it seems possible to distinguish this activity from meat removal in the archaeological record by considering several lines of evidence. In meat removal, longitudinal cutmarks should coincide with large muscle masses, and therefore, are expected to be more abundant on the meatiest bones (humerus and femur). In contrast, longitudinal cutmarks generated during periosteum removal should be more randomly located. Moreover, Costamagno and David (2009) emphasized that these marks will tend to be associated with scrape marks and should occur at higher frequencies on the tibia, radio-ulna, and metapodials. These observations thus suggest that cutmarks located on meaty bones are more likely to be produced during meat removal than during periosteum extraction.

Numérotation de l'auteur (non similaire à la publication) : 3 
Actualistic analyses suggest that defleshing cutmarks are mostly short and transverse or oblique (Binford, 1981; Bez, 1995; Abe, 2005; Vigne, 2005; Thiébaut et al., 2011). These cutmarks are generally located on long bone shafts, especially near zones of muscle attachments and tendinous insertions. The ethnoarchaeological and experimental evidence suggests that longitudinal cutmarks are rarely produced during simple defleshing. When defleshing is performed after boiling - a common practice for groups that live in cold areas (e.g., Abe, 2005; Costamagno and David, 2009) - most of the meat can easily be taken off without the help of a knife, as pointed out by Abe (2005:158) on the basis of observations among Evenki (northern Transbaikalia, Russia) herders. This last finding implies that cutmarks are unlikely to be produced in large quantities when meat is removed after boiling. When present, cutmarks tend to be short and oblique or transverse.

Filleting meat for drying is another well-documented practice (e.g., Stefansson, 1913; Jenness, 1922; Binford, 1978; Malaurie, 1990; Fallon Morel and Enig, 2000; Odgaar, 2007; Robert-Lamblin, 2007). Although rarely defined explicitly, filleting is generally understood to be an act aimed at removing long cuts or slices of meat of roughly standardized shape (i.e., fillets), whereas defleshing is usually described as an activity during which no particular focus is put on the morphology or size of the meat portions. Binford (1981: 128-129) indicated that when drying caribou (Rangifer tarandus) meat, the Nunamiut of Alaska produce: "filleting marks [that] are almost exclusively longitudinally oriented with respect to the bones on which they appear. The very act of filleting dictates this pattern [...] There are generally two types of cuts: (a) initial long, longitudinally oriented, bone-exposing cuts, and (b) shorter, more oblique cuts made to the underside of the exposed bone to free it from the mass of meat and/or sever muscle insertions." Similar observations were made by Nilssen (2000:135-136), who observed that the production of biltong (dried meat) in South Africa is typically associated with cutting motions that are "predominantly diagonal to longitudinal to the long axis of the bone," although some transverse or oblique gestures are sometimes necessary to detach the muscles. Both sets of observations emphasize the fact that oblique and transverse short cutmarks are commonly associated with long longitudinal cutmarks when removing meat fillets for drying.

In essence, the actualistic literature on meat removal suggests that boiled meat processing leaves few cutmarks, the majority of which are short and oblique/transverse. The literature also indicates that long longitudinal cutmarks are rarely produced on meaty regions of long bones during carcass processing activities and, when they do occur - usually at low to moderate frequencies - they are intimately associated with filleting and meat drying. Given these differences, analyzing the orientation and length of cutmarks in an assemblage may aid in interpreting meat processing strategies. Following this logic, in the remainder of this paper we use quantitative data from Nilssen (2000) and Abe (2005) as frames of reference for discussing meat processing activities in the Late Pleistocene record of France.

\section{Materials and methods}

The present study is primarily concerned with meat processing. Activities indicative of primary butchering (i.e., partitioning and segmentation of carcasses) and procurement of soft tissues for use as raw material (e.g., skin, sinew) are not investigated here. To gain knowledge about how attitudes toward meat varied during the Late Pleistocene, the present analysis focuses exclusively on the four long bones (the humerus, radio-ulna, femur, and tibia) that are associated with large muscle masses in terrestrial ungulates. Focusing on these four elements de facto excludes most cutmarks related to evisceration, skinning, and sinew removal because these marks areaccording to the actualistic literature-rarely encountered on the selected bones. As shown below, most of the cutmarks examined here are located on - or adjacent to - the mid-shaft portion of the long bones, and thus, are incompatible with disarticulation. However, because cutmarks were sometimes observed near or on the extremities of the shaft, our sample likely contains a small proportion of cutmarks produced during disarticulation.

The quantification of cutmarks has long been recognized as a major challenge in faunal analysis, as many variables - including differences in recording procedures between analysts - may influence its expression (e.g., Lyman, 1987, 1994, 2005; Abe et al., 2002; Lupo and O'Connell, 2002; Domínguez-Rodrigo, 2003; Egeland, 2003; Domínguez-Rodrigo and Yravedra, 2009; Otárola-Castillo, 2010; Costamagno, 2012). Some of these challenges are avoided here by using the number of cutmarks (Ncut) - which is simply a tally of the number of cutmarks counted in an illustration - as a basic quantitative unit. 
To investigate meat processing strategies, comparisons with control samples are critical. We are aware of only two actualistic studies - one by Nilssen (2000), the other by Abe (2005) - that comprise illustrated cutmark data on meat removal. The actualistic data provided by Abe (2005) focuses on the Evenki from the Kalarsky area (Russia). Among this group, meat is boiled attached to the bone. The cutmarks that Abe illustrated are from various reindeer (Rangifer tarandus, MNE $=8-12$ ) and musk deer (Moschus moschiferus, MNE $=3-8$ ) elements. Five different skilled butchers processed the carcasses using metal knives with 15-20 cm long blades. Unfortunately, Abe's illustrations pool all activities, which means that cutmarks produced during defleshing cannot be isolated from those generated during other tasks. As mentioned above, boiled meat is very easily detached from the bone. For this reason, it is not surprising to note that Abe's illustrations show relatively few cutmarks $(\mathrm{Ncut}=237)$.

Nilssen's (2000) experiments include detailed observations of small (steenbok Raphicerus campestris: $\mathrm{MNI}=1$; springbok Antidorcas marsupialis: $\mathrm{MNI}=4-7$, depending on the skeletal element) and large African bovids (blesbok Damaliscus dorcas phillipsi: $\mathrm{MNI}=1$; black wildebeest Connochaetes gnou: $\mathrm{MNI}=3$; eland Taurotragus oryx: $\mathrm{MNI}=3$ ) processed for biltong and sausage in the Karoo region of South Africa. Several carcasses were defleshed by a single person, described as an "expert butcher" (Nilssen, 2000:27). The other carcasses were butchered by meat and trophy hunters for the same purposes. Processing was conducted with metal $(85 \%)$ and, less frequently, stone (15\%) tools. Although a large number of individual filleting cutmarks $($ Ncut $=898)$ were recorded in Nilssen's experiments, only one cutmark was observed on the radio-ulna. Consequently, this element was excluded from our analysis. The present analysis also omits 'shave marks,' which are identified by ellipses in Nilssen's illustrations (Nilssen, pers. comm., 2014) and by the letter 'O' in Abe's drawings. These marks occur when "the knife blade is used at an acute angle to the bone surface and is moved in a direction perpendicular to the length of the blade causing a portion of cortical bone to be shaved away" (Nilssen, 2000:38). Like scrape marks, shave marks are omitted here because their orientation and length could not be assessed precisely on the drawings.

Another issue with the South African data is that cutmarks are sometimes repeated on the drawings rather than drawn only once (Nilssen 2000:42). A close examination of the illustrations suggests that this problem of duplication mostly involves transverse and oblique cutmarks located at the extreme left or extreme right of a bone template. Unfortunately, we could not simply eliminate the duplicated cutmarks from the sample, as these are not identified on the drawings. Our verifications suggest that few, if any, longitudinal cutmarks are repeated on different views of the same bones. Duplication of some transverse/oblique cutmarks should artificially increase the representation of this type of cutmarks. Moreover, we cannot exclude the possibility that single cutmarks have been divided and represented on different views of the same bone. In this case, the effect should be to slightly decrease the representation of long cutmarks in the sample.

\section{The archaeological sample}

The archaeological sample examined in the present study is dominated by sites from southwest France (Fig. 1), a region for which a large number of archaeozoological analyses have been published. Our sample comprises 27 anthropogenic assemblages for which cutmark illustrations were available (Table 1). The data that we used come from our own observations and several published studies (Delpech and Villa, 1993; Deplano, 1994; Cho, 1998; Castel, 1999, 2003, 2011; Costamagno, 1999; David and Poulain, 2002; Turner, 2002; Tolmie, 2013). The available information from the published studies suggests that cutmarks were observed with a hand lens for a majority of these assemblages, as was the case for the assemblages that we personally examined. 


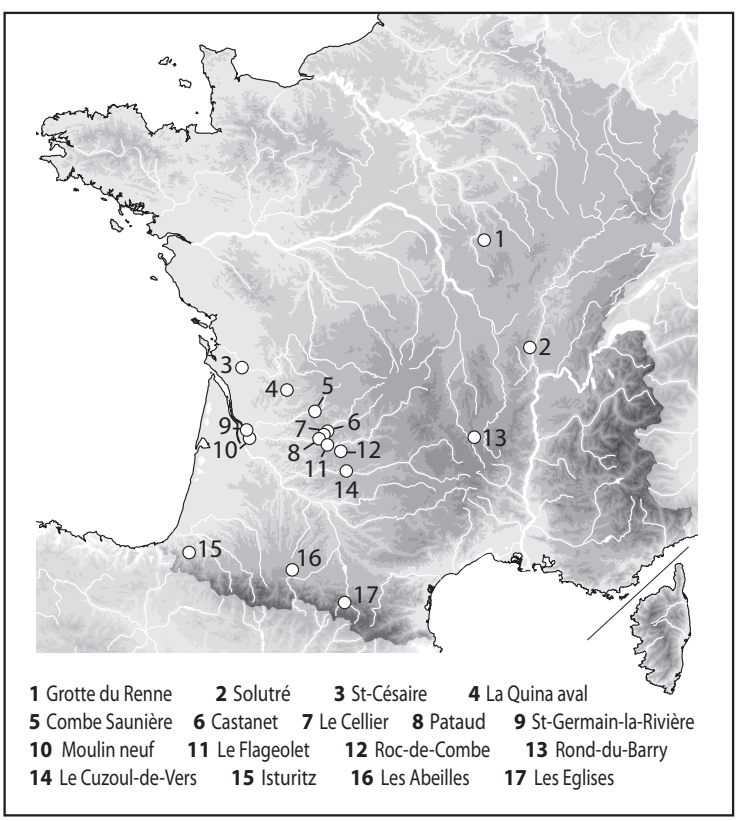

Figure 1. Location of the archaeological assemblages.

With the exception of Solutré, which is an open-air site, all assemblages are from caves or rockshelters. The assemblages are spread over a relatively long time span, with occupations ranging from the final Mousterian (c. $45 \mathrm{ka} \mathrm{BP}$ ) to the end of the Magdalenian (c. $12 \mathrm{ka} \mathrm{BP}$ ). However, temporal coverage is uneven, with the sample being dominated by assemblages dated to the Aurignacian (11/27 or $40.7 \%$ ) and Magdalenian (8/27 or $29.6 \%)$. Overall, Ncut sample sizes vary by more than two orders of magnitude within the dataset (range: 14-5824; total Ncut $=20,035$ ). Nonetheless, for most assemblages $(20 / 27$ or $74.1 \%)$, sample sizes are large (Ncut $>100)$. For the vast majority of assemblages included in the sample, faunal preservation is reported as "good." Although the degree of bone surface preservation varies within the archaeological sample, cutmark orientation and measurement patterns should be mostly unaffected by this variable, as preservation is assumed to be largely independent of the type of cutmarks present (e.g., transverse or longitudinal, short or long).

The analysis of the archaeological assemblages was limited to the examination of three roughly similarly-sized ungulates: reindeer Rangifer tarandus $(n=21$ assemblages), saiga Saiga tatarica $(n=3$ assemblages), and ibex Capra ibex/pyrenaica ( $n=3$ assemblages). Therefore, variation due to body size is largely accounted for in the archaeological sample. However, at a finer level of detail, it should be noted that the saiga (36-69 kg: Dolan, 1987) and ibex (35-80 kg: Lorvelec and Vigne, 2003) tends to be somewhat smaller than reindeer (60-150 kg: Kelsall, 1968; Geist, 1998). Potential issues arising from differences in body size, along with those that affect the control sample, are reviewed below. 
Table 1. The sample of assemblages presented by time period and species. ${ }^{\mathrm{a}}$

\begin{tabular}{|c|c|c|c|c|}
\hline Time period/Assemblage & Abbreviation & Ncut & Taxon $^{b}$ & Reference \\
\hline \multicolumn{5}{|l|}{ Late Magdalenian } \\
\hline Les Églises & lesEgl LMag & 628 & 1 & Delpech and Villa, 1993 \\
\hline Rond-du-Barry E & RdB E LMag & 707 & 1 & Costamagno, 1999 \\
\hline Solutré P16 & Solut LMag & 14 & $\mathrm{R}$ & Turner, 2002 \\
\hline \multicolumn{5}{|l|}{ Middle Magdalenian } \\
\hline Moulin-Neuf & MNeuf MMag & 369 & $\mathrm{~s}$ & Costamagno, 1999 \\
\hline Le Flageolet IX & Le Flag MMag & 273 & $\mathrm{R}$ & Deplano, 1994 \\
\hline \multicolumn{5}{|l|}{ Early Magdalenian } \\
\hline Saint-Germain-la-Rivière 1 & St-Ger1 EMag & 2321 & $\mathrm{~s}$ & Costamagno, 1999 \\
\hline Saint-Germain-la-Rivière 3-4 & St-Ger3-4 EMag & 694 & $\mathrm{~s}$ & Costamagno, 1999 \\
\hline \multicolumn{5}{|l|}{ Badegoulian } \\
\hline Rond-du-Barry F2 & RdB F2 Bad & 971 & 1 & Costamagno, 1999 \\
\hline Le Cuzoul-de-Vers 23 & CuzV Bad & 734 & $\mathrm{R}$ & Castel, 2003 \\
\hline \multicolumn{5}{|l|}{ Solutrean } \\
\hline Le Cuzoul-de-Vers 31-29 & CuzV Sol & 274 & $\mathrm{R}$ & Castel, 1999 \\
\hline Combe Saunière IV & ComSau Sol & 1429 & $\mathrm{R}$ & Castel, 1999 \\
\hline \multicolumn{5}{|l|}{ Gravettian } \\
\hline Pataud 3 & Pataud Gr & 578 & $\mathrm{R}$ & Cho, 1998 \\
\hline \multicolumn{5}{|l|}{ Evolved Aurignacian } \\
\hline Saint-Césaire EJM, EJJ & StC EvAuri & 96 & $\mathrm{R}$ & This study, SOM Fig. 1 \\
\hline \multicolumn{5}{|l|}{ Middle Aurignacian } \\
\hline Saint-Césaire EJO sup, EJF & StC MAuri & 769 & $\mathrm{R}$ & This study, SOM Fig. 2 \\
\hline \multicolumn{5}{|l|}{ Early Aurignacian } \\
\hline Isturitz C4b, C4l, E4la, E4lb & Ist EAuri & 945 & $\mathrm{R}$ & Soulier, 2013 \\
\hline Les Abeilles 1 & Abei EAuri & 1100 & $\mathrm{R}$ & Soulier, 2013 \\
\hline La Quina aval & QuAv EAuri & 5824 & $\mathrm{R}$ & Soulier, 2013 \\
\hline Cellier & Cellier EAuri & 29 & $\mathrm{R}$ & Tolmie, 2013 \\
\hline Castanet & Cast EAuri & 621 & $\mathrm{R}$ & Castel, 2011 \\
\hline Roc-de-Combe 7 & RdC EAuri & 813 & $\mathrm{R}$ & Soulier, 2013 \\
\hline \multicolumn{5}{|l|}{ Protoaurignacian } \\
\hline Isturitz C4c6-12, C4d1, C4III & Ist ProtA & 214 & $\mathrm{R}$ & Soulier, 2013 \\
\hline Les Abeilles 2,3 & Abei ProtA & 59 & $\mathrm{R}$ & Soulier, 2013 \\
\hline Grotte du Renne VII & GrRen ProtA & 85 & $\mathrm{R}$ & David and Poulain, 2002 \\
\hline \multicolumn{5}{|l|}{ Châtelperronian } \\
\hline Grotte du Renne Xc & GrRen Chât & 112 & $\mathrm{R}$ & Tolmie, 2013 \\
\hline Roc-de-Combe 8 & RdC Chât & 237 & $\mathrm{R}$ & Soulier, 2013 \\
\hline La Quina aval & QuAv Chât & 50 & $\mathrm{R}$ & Soulier, 2013 \\
\hline \multicolumn{5}{|l|}{ Mousterian } \\
\hline Saint-Césaire EGPF, EJOP inf & StC Moust & 89 & $\mathrm{R}$ & This study, SOM Fig. 3 \\
\hline
\end{tabular}

a The sample size (Ncut) gives the total number of digitized cutmarks.

${ }^{b} \mathrm{R}=$ Reindeer, $\mathrm{S}=$ Saiga, $\mathrm{I}=\mathrm{Ibex}$.

\section{Analytical methods and limitations of the study}

Length ('magnitude') and angle of orientation ('azimuth') of cutmarks were estimated using published drawings and our own observations for several archaeological assemblages. In most instances, we were able to verify with the authors of the primary publications that their illustrations were, like ours, drawn to scale. Concerning the other cases (i.e., Delpech and Villa 1993; Deplano 1994; Cho 1998; David and Poulain 2002; Tolmie 2013), the varying, rather than standardized or schematic, length and orientation of the cutmarks in the illustrations suggest that they were also drawn to scale. Given that individuals likely vary in their ability to faithfully reproduce cutmark drawings, the possibility of systematic bias between different authors cannot be excluded, a problem that is probably most acute for length estimations than for orientations. To obtain comparable measurements, each cutmark was re-drawn in Illustrator ${ }^{\mathrm{TM}}$ according to standard templates (Fig. 2). Once all at the same scale, the vectorized cutmarks were imported, and measurements made, in QGIS (version 2.0.1-Dufour: QGIS, 2013) and compiled in a spreadsheet. Note that because we used drawings rather than direct observations, the direction of the strokes is unknown in all cases. Consequently, angles of orientation in the sample range between $0-180^{\circ}$ and were calculated using the proximal end of the long bone as the geographic "north." Cutmark length distributions were examined after logarithmic transformation, the raw values presenting a positive skew. To assess the location of the cutmarks, long bones were divided into five portions (Fig. 2) as in Abe et al. (2002). These methods, along with those described below, were used for both the actualistic and archaeological samples. 

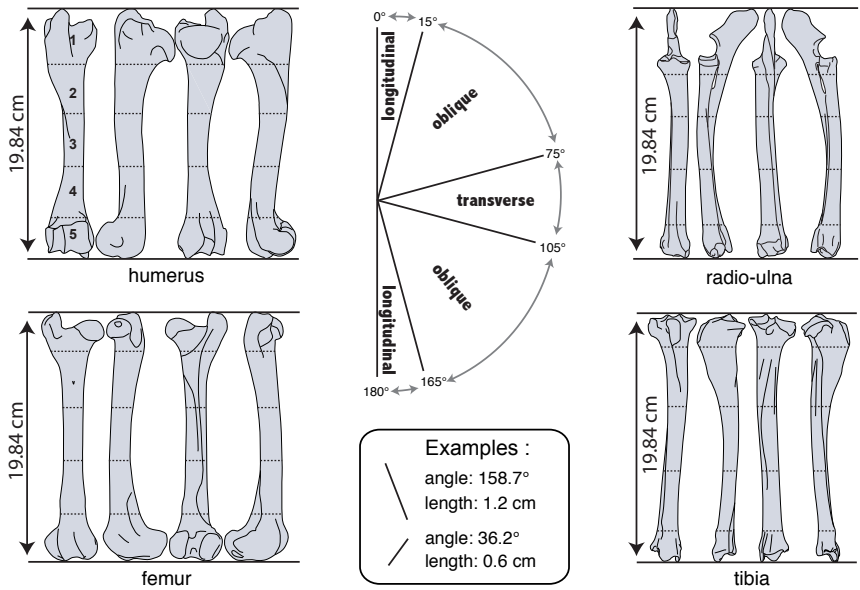

Figure 2. The bone templates used in this study. Numbers $1-5$ on the bones designate bone portions. Note that the length of the long bone elements is in 'Illustrator cm' (see text).

Length values provided here are not actual measurements made on the specimens themselves, but rather measurements made relative to our Illustrator templates. Thus, our measurements are unitless and were derived using long bone drawings that all have the same (arbitrary) length (19.84 'Illustrator cm'). This means that, under this approach, a cutmark spanning $1 / 10^{\text {th }}$ of a saiga humerus and one spanning $1 / 10^{\text {th }}$ of an eland tibia are both associated with the same length measurement. This approach was used for two reasons. First, scaling seems necessary with these types of data because meat removal gestures are expected to have varied as a function of the size of the muscle masses. In other words, 'long' is, by definition, a relative term; it depends on the size of the bone one is processing. For instance, a 'long' cutmark on a rabbit tibia will be actually quite short relative to a 'long' cutmark on the tibia of an elephant. Second, the illustrations that we consulted are themselves compilations of scaled measurements; the various authors who produced them used standard templates that ignore sex, age, and intra-specific variation in body size. Importantly, the use of scaled measurements should facilitate comparison of taxa, an issue of significance in the present case as species vary within and between the samples.

To analyze the data, we compiled frequency distributions according to 12 classes of $15^{\circ}\left(0-15^{\circ}, 15-30^{\circ}\right.$, etc.) for the orientation data and 10 classes of 0.33 for the log 10 -transformed measurements (starting with -2.5$-2.17,-2.17-1.84$, etc.). These classes were selected because they provide a convenient way of breaking down the quantitative information. Because our sample includes a large number of assemblages, the above classes were combined into three larger categories in the figures: longitudinal $\left(0-15^{\circ}\right.$ and $\left.165-180^{\circ}\right)$, oblique $\left(15-75^{\circ}\right.$ and $\left.105-165^{\circ}\right)$, and transverse $\left(75-105^{\circ}\right)$ for the orientation data, and short $(<-1.18)$, intermediate $(-1.18-0.14)$, and long $(>0.14)$ for the $\log 10$-transformed length measurements. To assess variations in proportion of categories of cutmarks, the equality of percentages was examined after arcsine-transformation of the data using Sokal and Rohlf's (1969) $t$ statistic (denoted $\mathrm{t}_{\mathrm{s}}$ ). Cochran's test for linear trend (Cannon, 2001) was used to ascertain the statistical robustness of temporal patterns in the archaeological sample. Following standard procedure, statistical tests are considered significant when $p<0.05$.

Unlike length measures, orientation data cannot be studied using standard descriptive statistics because angle measurements have no true zero and because the direction of increase or decrease is defined in an arbitrary way along a circular scale (Zar, 2010). Consequently, trends in our data were examined from the perspective of circular (directional) statistics (Batschelet, 1981). To explore patterns in cutmark orientations, we took advantage of the rose diagrams and mean vectors generated by Stereonet (v. 9.0.4, Cardoso and Allmendinger, 2013), whereas correlations between angular and linear measurements were calculated in Oriana v. 4 (Kovach, 2011). Preferential orientation of cutmarks was assessed in the sample using Curray's (1956) vector magnitude $L$, a twodimensional statistic commonly used in fabric analysis (e.g., Bertran and Texier, 1995; Lenoble and Bertran, 2004). Generally, the higher the $L$, the stronger the pattern of orientation. In this approach, an $L=0$ implies a random distribution, whereas an $L=100$ means that all the cutmarks have the same orientation. Following Curray (1956) and Lenoble and Bertran (2004), $L$ is calculated in the following manner: 
$L=100 \times r / n$

where $n$ is sample size

$\alpha$ being the orientation between $0-180^{\circ}$.

$$
\text { and } r=\sqrt{ }\left[\left(\Sigma^{n} \sin 2 \alpha\right)^{2}+\left(\Sigma^{n} \cos 2 \alpha\right)^{2}\right]
$$

Note that to obtain circular series, angles are doubled in the calculation of $r$. We used the Rayleigh test of uniformity to determine probability (Lenoble and Bertran, 2004):

$$
p=\exp \left(-L^{2} \times n\right) / 10000
$$

The hypothesis of a uniform distribution of the orientations is rejected when $p<0.05$. The Rayleigh test assumes a von Mises distribution, the circular equivalent of a normal distribution (Zar, 2010). However, because assemblages in our sample may better fit a bimodal axial distribution - a distribution in which the two modes are opposed at $180^{\circ}$ - than a unimodal distribution, an alternative approach was also considered for all assemblages. To test for axially distributed cutmark orientations, we doubled the orientation measures in the circular series to obtain vector magnitude $L_{2}$. This procedure causes the two modes to merge, thereby permitting a meaningful comparison with a von Mises distribution (Batschelet, 1981). If $L_{2}$ increases relative to $L$ and is statistically significant, we concluded that the values were consistent with a bimodal axial distribution. One limitation with this approach is that it flattens the distribution, with the implication that weakly oriented data may fail to achieve statistical significance. In addition, the test may fail to detect bimodal distributions for non-axially distributed data. Therefore, the test is conservative when it comes to identifying non-random distributions (Lenoble and Bertran, 2004). Although there are other tests (e.g., mixture of von Mises distributions) for detecting complex bimodal or multimodal distributions (Fischer, 1993), these are computationally complex and make assumptions that may not always be possible to assess in our sample.

Despite their obvious significance for the analysis of Paleolithic cutmarks, the actualistic results examined here are not entirely comparable to those collected in archaeological contexts. For instance, Nilssen (2000) emphasized that the use of a steel knife with a $10 \mathrm{~cm}$ blade in most of the butcheries that he observed may have resulted in marks that may not be possible to replicate with stone tools. These observations extend to the ethnoarchaeological data collected by Abe (2005), as her Evenki informants also used metal blades. Thus, some types of cutmarks - perhaps including most shave marks - may only occur in the actualistic samples because a metal blade was employed. Whether these differences have a significant impact on comparisons with Paleolithic assemblages is a possibility that remains to be explored more fully.

Another important limitation is that Nilssen's (2000) and, to a lesser extent Abe's (2005), data are for species that differ, to some extent, in terms of musculature and limb proportions with reindeer. Therefore, scaling cutmarks according to a reindeer model potentially slightly influenced the measurements in the present study. Last, the fact that shaft fragments with truncated cutmarks may be present in the archaeological sample likely decreases the representation of long cutmarks relative to Nilssen's sample, which only includes complete long bones. Notwithstanding these issues, Nilssen's and Abe's actualistic data provide a valuable source of control information for investigating meat processing behavior in the Late Pleistocene. The entire dataset collected for this study is accessible in the Supplementary Online Material (SOM Tables 1-2) associated with this article.

\section{Results}

\section{The actualistic sample}

The South African sample shows a tendency for longitudinal cutmarks to be longer than transverse ones (Fig. 3a). This pattern is seen in both small $\left(0-90^{\circ}\right)$ and large $\left(90-180^{\circ}\right)$ angles, although the circular-linear correlations indicate that the trend is stronger for the small angles $\left(0-90^{\circ}, r=0.44, p<0.0001 ; 90-180^{\circ}, r=0.30\right.$, $p<0.0001$ ). Longitudinal cutmarks may be longer simply because a transverse cutting motion on a roughly cylindrical bone is only going to intersect the bone at a plane tangential to the bone surface - possibly resulting in mostly short cutmarks - whereas in a longitudinal cutting motion the tool's edge can potentially intersect the bone throughout the entire length of the cut. In the Evenki dataset, the trends are weak and only significant for the wider angles $\left(0-90^{\circ}, r=0.10, p=0.27 ; 90-180^{\circ}, r=0.18, p=0.04\right.$, Fig. 3b). These weak trends possibly reflect the poor representation of long strokes in the reindeer and musk deer samples. 

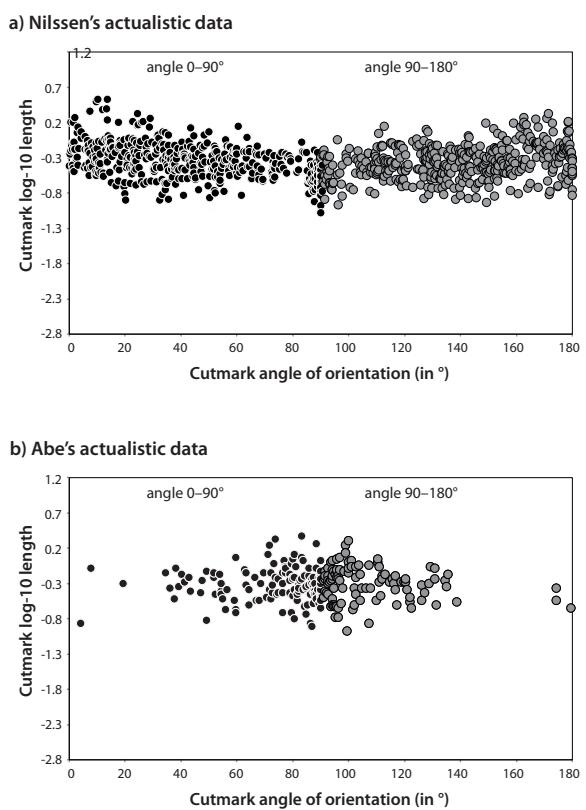

Figure 3. Scatterplot showing the relationship between cutmark log10-length and cutmark angle of orientation (in ${ }^{\circ}$ ) in the actualistic samples collected by: a) Nilssen (2000) and b) Abe (2005). The left and right circles denote angles between $0-90^{\circ}$ and 90 $180^{\circ}$, respectively. No regression lines are shown because the plots includes angular measurements. The raw measurement data are available in the SOM, Table 1.
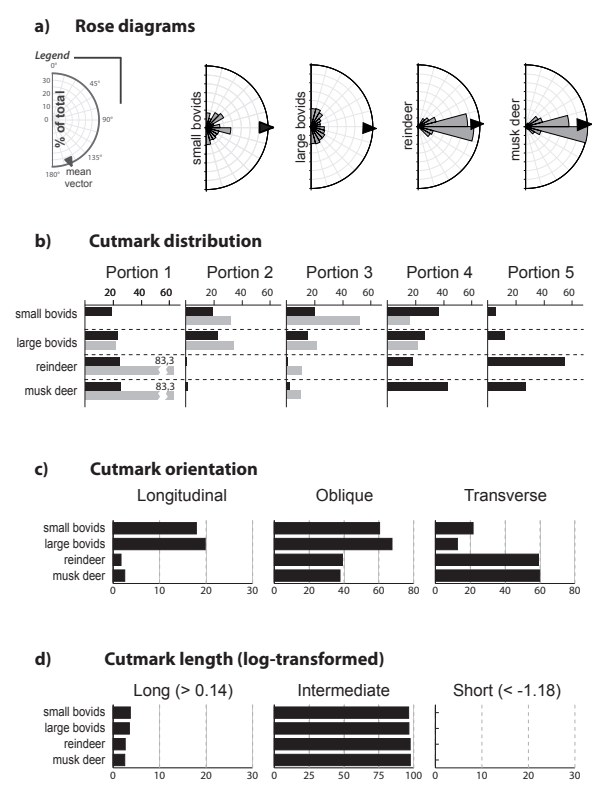

Figure 4. Data on cutmark orientation and length in Nilssen's (2000) and Abe's (2005) actualistic samples: a) rose diagrams of cutmark orientations (the arrows show the mean angle ['mean vector'] for each of the samples); b) cutmark distribution by bone portion for the stylopodium (black bars) and zeugopodium (gray bars); c) percentages of longitudinal, oblique, and transverse orientations; and d) percentages of long, intermediate, and short cutmarks. Percentages were calculated relative to the total assemblage sample. The raw measurement data are available in the SOM, Table 1.

Table 2. Frequency distributions of $\log 10$-transformed cutmark lengths and angles of orientation (in ${ }^{\circ}$ ) for Nilssen's (2000) and Abe's (2005) actualistic samples. ${ }^{a}$

\begin{tabular}{|c|c|c|c|c|c|c|c|c|c|c|c|c|}
\hline \multicolumn{13}{|c|}{ Log10-transformed length } \\
\hline & & $\begin{array}{l}-2.5- \\
-2.17\end{array}$ & $\begin{array}{c}-2.17- \\
-1.84 \\
\end{array}$ & $\begin{array}{r}-1.84- \\
-1.51\end{array}$ & $\begin{array}{c}-1.51- \\
-1.18\end{array}$ & $\begin{array}{r}-1.18- \\
-0.85 \\
\end{array}$ & $\begin{array}{r}-0.85- \\
-0.52 \\
\end{array}$ & $\begin{array}{c}-0.52- \\
-0.19 \\
\end{array}$ & $\begin{array}{c}-0.19- \\
0.14\end{array}$ & $\begin{array}{c}0.14- \\
47\end{array}$ & $\begin{array}{c}0.47- \\
0.80\end{array}$ & \\
\hline Small & & - & - & - & - & 1.8 & 29.7 & 46.9 & 18.0 & 2.9 & 0.7 & \\
\hline Large & & - & - & - & - & 1.6 & 20.5 & 52.3 & 22.1 & 3.4 & 0.2 & \\
\hline Reindeer & & - & - & - & - & 2.6 & 27.0 & 45.2 & 22.6 & 2.6 & - & \\
\hline M. deer & & - & - & - & - & 1.6 & 9.8 & 54.1 & 32.0 & 2.5 & - & \\
\hline \multicolumn{13}{|c|}{ Orientation (in ${ }^{\circ}$ ) } \\
\hline & $\begin{array}{l}0- \\
15^{\circ}\end{array}$ & $\begin{array}{c}15- \\
30^{\circ}\end{array}$ & $\begin{array}{l}30- \\
45^{\circ}\end{array}$ & $\begin{array}{c}45- \\
60^{\circ}\end{array}$ & $\begin{array}{l}60- \\
75^{\circ}\end{array}$ & $\begin{array}{c}75- \\
90^{\circ}\end{array}$ & $\begin{array}{l}90- \\
105^{\circ}\end{array}$ & $\begin{array}{c}105- \\
120^{\circ}\end{array}$ & $\begin{array}{c}120- \\
135^{\circ}\end{array}$ & $\begin{array}{r}135- \\
150^{\circ}\end{array}$ & $\begin{array}{c}150- \\
165^{\circ}\end{array}$ & $\begin{array}{c}165- \\
180^{\circ}\end{array}$ \\
\hline Small & 8.4 & 5.5 & 9.9 & 11.4 & 4.4 & 7.7 & 13.9 & 7.3 & 7.0 & 7.7 & 7.3 & 9.5 \\
\hline Large & 10.2 & 10.6 & 9.1 & 6.4 & 5.4 & 5.1 & 7.5 & 8.0 & 9.0 & 9.0 & 10.1 & 9.6 \\
\hline Reindeer & - & - & 5.2 & 7.0 & 10.4 & 27.8 & 31.3 & 8.7 & 7.8 & - & - & 1.7 \\
\hline M. deer & 1.6 & 0.8 & 2.5 & 8.2 & 9.8 & 24.6 & 35.2 & 9.0 & 5.7 & 1.6 & - & 0.8 \\
\hline
\end{tabular}

a The column headings are the size classes and the angle classes, respectively. "Small" and

"large" refer to small and large bovids; "m. deer" stands for "musk deer." 
The rose diagrams (Fig. 4a, Table 2) and the low $L$ and $L_{2}$ values for the actualistic South African sample reveal no preferential orientation of the cutmarks for the small bovids $\left(L=5.3, L_{2}=4.2, p=0.47\right)$ and only a weak, yet highly significant, unimodal trend among the large bovids $\left(L=13.3, L_{2}=6.1, p<0.0001\right)$. In the Evenki sample, the distributions of the cutmarks are very different as they are strongly unimodal, which is verified statistically (reindeer: $L=73.8, L_{2}=41.0, p<0.0001$; musk deer: $L=71.2, L_{2}=39.5, p<0.0001$ ). The Evenki data also show that cutmarks are common on the joints and occur at lower frequencies on the shafts (Fig. 4b). In the South African sample, the cutmarks tend to follow the opposite pattern.

In general, most cutmarks have either an oblique or transverse orientation, the latter being particularly abundant in the Evenki data (Fig. 4c). Longitudinal cutmarks are statistically as common in the small (17.9\%) as the large $\left(19.8 \%, \mathrm{t}_{\mathrm{s}}=0.67, p=0.50\right)$ bovids, but are rare on reindeer and musk deer $(<3.0 \%)$. With respect to dimensions, most cutmarks are of intermediate length (Fig. 4d), whereas short cutmarks are entirely absent from all four assemblages. In the South African sample, there are comparably low proportions of long cutmarks in small versus large bovids (small: $3.7 \%$; large: $3.5 \%$; $t_{s}=0.15, p=0.88$ ). Thus, these data suggest only minor differences in terms of how meat is filleted in small and large bovids. We note that long cutmarks are slightly less frequent in the Evenki data.

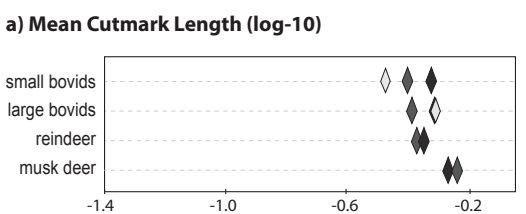

c) $\%$ of Longitudinal $\left(0-15^{\circ}\right.$ and $\left.165-180^{\circ}\right)$ Cutmarks

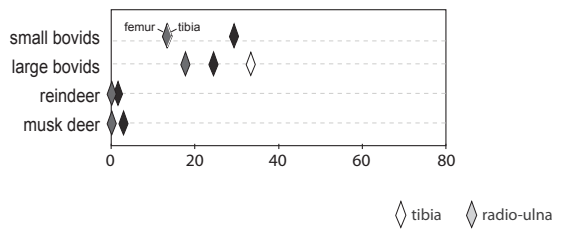

$\Delta$ tibia $\Delta$ radio-ulna b) $\%$ of Transverse $\left(75-105^{\circ}\right)$ Cutmarks

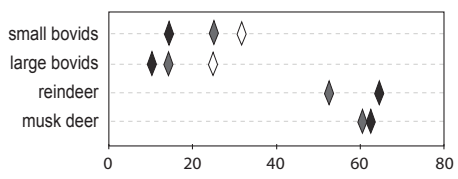

d) \% of Long Cutmarks

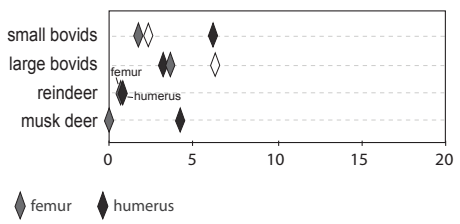

Figure 5. Data on cutmark orientation and length in Nilssen's (2000) and Abe's (2005) actualistic samples presented by skeletal element: a) mean cutmark log10-length, b) percentages of transverse cutmarks, c) percentages of longitudinal cutmarks, and d) percentages of long cutmarks. Percentages were calculated relative to the total sample for the selected element and assemblage. The raw measurement data are available in the SOM, Table 1.

Figure 5 provides information for the same datasets, this time partitioned by skeletal element. Average $\log 10$-transformed length measurements show a relatively narrow range of variation (from -0.5 to -0.2 ) between the different bones, with a tendency for musk deer to have larger cutmarks (Fig. 5a). The data also indicate that transverse cutmarks on the femur and humerus occur at higher frequencies in the Evenki sample than in the South African sample (Fig. 5b). We note that longitudinal cutmarks (Fig. 5c) are rare on Evenki elements and are more common on the tibia of large than on the tibia of small bovids. The trend for the tibia is weakly significant ( 31.3 versus $\left.11.4 \%, t_{s}=2.15, p<0.04\right)$. Long cutmarks occur in low percentages in all classes of long bones irrespective of the dataset (Fig. 5d). Overall, we note that, in the South African sample, longitudinal cutmarks are reasonably frequent (17.9-19.8\%), whereas long cutmarks are uncommon $(3.5-3.7 \%)$.

\section{Archaeological results and comparisons with the control sample}

The archaeological assemblages examined here are strongly dominated by fragments from the shaft region, with the extremities being very poorly represented, a pattern that de facto excludes most disarticulation cutmarks. This pattern — which is emphasized in most of the original studies (Delpech and Villa, 1993; Deplano, 1994; Cho, 1998; Castel, 1999, 2011; Costamagno, 1999; David and Poulain, 2002; Morin, 2012; Soulier, 2013, 2014; Soulier et al., 2014; Tolmie, 2014)_has many possible causes, including the use of epiphyses as fuel, the differential preservation of spongy versus compact bone, or the selective destruction of these tissues during bone grease rendering or through carnivore ravaging. Regardless of causes, the very low representation of epiphyses in the archaeological sample finds support in Figure 6, which shows that most cutmarks are located on shaft bone portions. This trend accords well with the South African data but fits poorly with the Evenki data (Fig. 4b). The 
results also indicate that differences are small between the stylopodium (humerus and femur) and zeugopodium (radio-ulna and tibia), or between assemblages from distinct time periods. As a result of these patterns, it is probably safe to infer that cutmarks in the archaeological samples are mostly indicative of meat removal.

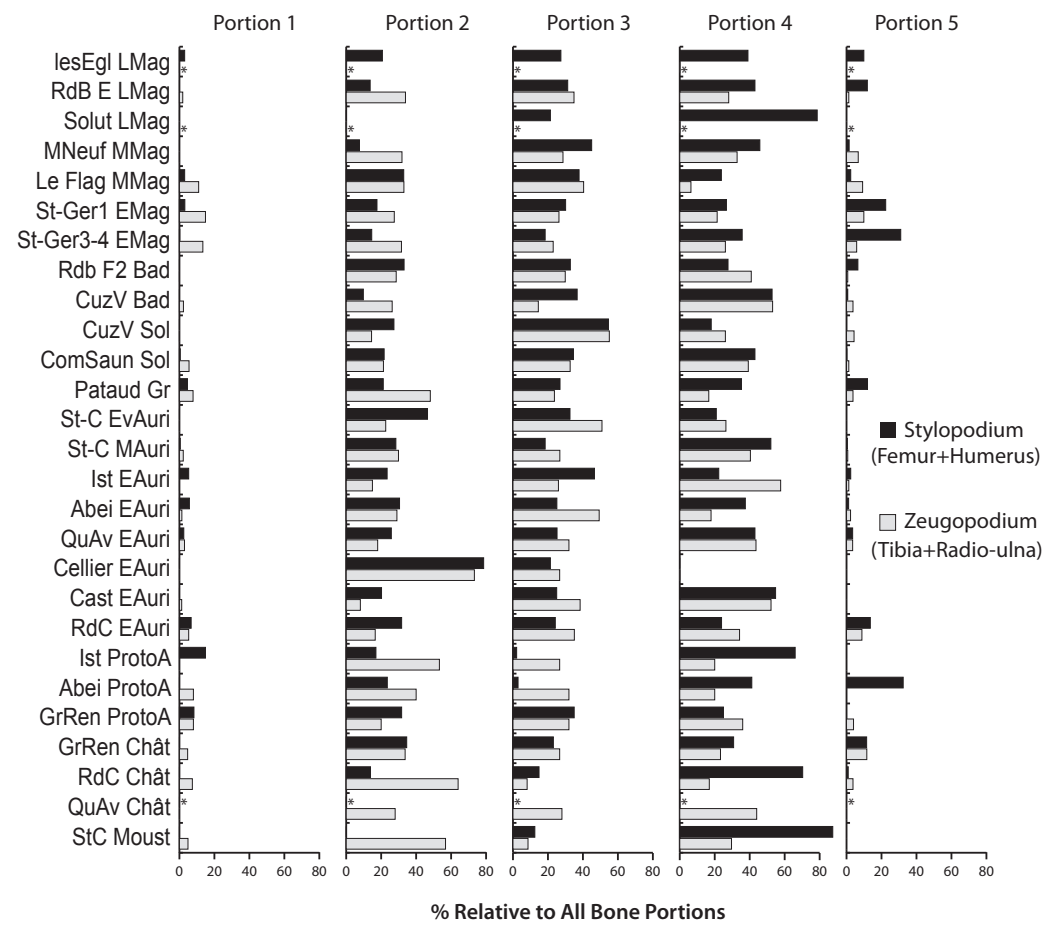

Figure 6. Distribution of cutmarks by bone portion for the stylopodium and zeugopodium in the archaeological sample. Percentages were calculated relative to all five bone portions (see Table 1 for the acronyms). An asterisk means that there are no cutmarks for the category of bones. The raw measurement data are available in the SOM, Table 2.

Figure 7. Scatterplot showing the relationship between cutmark $\log 10$-length and cutmark angle of orientation (in ${ }^{\circ}$ ) in the archaeological sample. The left and right circles denote angles between $0-90^{\circ}$ and $90-180^{\circ}$, respectively. No regression lines are shown because the plots include angular measurements. Abbreviations are as listed in Table 1. The raw measurement data are available in the SOM, Table 2.

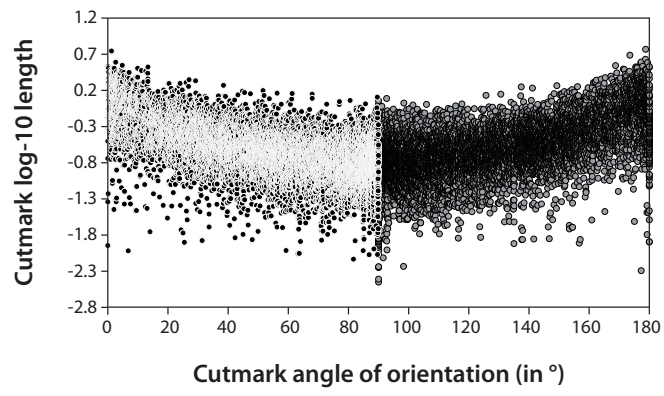

Figure 7 is a scatterplot that displays measurement data for the entire sample of archaeological cutmarks $($ Ncut $=20,035$ : Tables 3-4). Like the South African sample, the data point to the existence of a relationship between the length and the orientation of the cutmarks. As a rule, cutmarks are longer when longitudinal, a conclusion supported by relatively high circular-linear correlations $\left(0-90^{\circ}, r=0.61, p<0.0001 ; 90-180^{\circ}, r=\right.$ $0.63, p<0.0001)$. 
Table 3. Frequency distribution of the angles of orientation (in ${ }^{\circ}$ ) of the cutmarks in the archaeological sample. ${ }^{\mathrm{a}}$

\begin{tabular}{|c|c|c|c|c|c|c|c|c|c|c|c|c|}
\hline & $\begin{array}{l}0- \\
15^{\circ}\end{array}$ & $\begin{array}{l}15- \\
30^{\circ}\end{array}$ & $\begin{array}{l}30- \\
45^{\circ}\end{array}$ & $\begin{array}{l}45- \\
60^{\circ}\end{array}$ & $\begin{array}{l}60- \\
75^{\circ}\end{array}$ & $\begin{array}{r}75- \\
90^{\circ}\end{array}$ & $\begin{array}{l}90- \\
105^{\circ}\end{array}$ & $\begin{array}{r}105- \\
120^{\circ}\end{array}$ & $\begin{array}{c}120- \\
135^{\circ}\end{array}$ & $\begin{array}{r}135- \\
150^{\circ}\end{array}$ & $\begin{array}{c}150- \\
165^{\circ}\end{array}$ & $\begin{array}{r}165- \\
180\end{array}$ \\
\hline Egl & .9 & 7.3 & 4.9 & 8.9 & 4.1 & 6.7 & .7 & 4.5 & 7.5 & 9.9 & 2.3 & \\
\hline$B E$ & & 6.5 & 6.9 & 5.0 & 4.0 & 7.1 & & 2.5 & 9.1 & 4.9 & 1.0 & \\
\hline lut & & & & & 14.3 & 21.4 & 1 & 21.4 & 14.3 & 4.3 & 7.1 & \\
\hline Neu & 6.8 & 5.1 & 5.4 & 4.1 & 2.2 & 7.6 & 13.6 & 5.4 & 13.6 & 15.7 & 11.1 & 1.5 \\
\hline Flag & 2.2 & 9.2 & 10.3 & .7 & 2.9 & 26.7 & 20.9 & 2 & 2.2 & 11.7 & 5.5 & \\
\hline Gerit & 7 & 7.1 & 8.5 & 7.3 & 4.4 & 6.1 & & 5.2 & 6.4 & 6 & .5 & 12. \\
\hline Gers & 1.0 & 7.9 & 11.0 & 9 & 3.2 & 3.9 & 2.5 & 2.9 & 6.2 & 6.8 & 9.5 & \\
\hline IB F2 B & .9 & 9.3 & 8.5 & 8.0 & 0 & 9 & 9.2 & .4 & 8.2 & 9 & .4 & \\
\hline & 7.6 & 9.4 & 12.9 & 8.0 & 2.9 & 2.3 & 2 & 6.9 & 11.3 & 17.4 & 3 & \\
\hline & 7.3 & 7.3 & 10.9 & 1.3 & 4.4 & 5.1 & 11.7 & 3 & .3 & 2.4 & 9.9 & \\
\hline & & 6.7 & & & & 19 & & 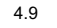 & .1 & 10.8 & 9.9 & \\
\hline & & & & & 13.1 & 24.9 & & & & & 1.7 & \\
\hline C Eve & 6.3 & 13.5 & & & - & 5.2 & & & .8 & 6 & .5 & \\
\hline C MAuri & 4.9 & & & & 3.4 & .3 & & & & & 0 & 19 \\
\hline EAur & 0.3 & $1 .{ }^{2}$ & & 10.7 & 17.0 & 23.1 & 2.3 & 10.5 & 5. & 3.5 & 2.1 & \\
\hline eit & 2.1 & 3.5 & 5.3 & 8.5 & 10.1 & 16.5 & 23.1 & 13.5 & 8.2 & 9 & 3.5 & .7 \\
\hline UAv & 0.9 & 3.0 & 4. & .7 & 9.6 & 20.8 & 29.6 & 11.3 & 5.6 & .1 & 2.0 & .3 \\
\hline ellie & - & - & 3. & 13.8 & 3.4 & 31.0 & 10.3 & 10.3 & 10.3 & 13.8 & 3.4 & \\
\hline & 4.0 & 9.5 & 11.0 & 12.1 & 10.5 & 5.8 & 6 & 3 & 6.6 & 7 & 9.7 & \\
\hline & 0. & 1.6 & & 7. & 2.4 & 1.0 & .3 & & & & 2 & \\
\hline & 0.5 & 3.3 & 2.8 & 9.3 & 21.0 & 25.2 & 9 & 3.1 & 3 & 3.3 & 1.9 & .5 \\
\hline ei $\mathrm{F}$ & - & 6.8 & 5. & 15.3 & 6.8 & 6. & 22.0 & 13.6 & & & 1.7 & \\
\hline Rer & 11.8 & 1.2 & 5. & 10.6 & 9. & 4.7 & 6 & 1 & & & & \\
\hline Rer & 0.9 & . & & 11.6 & 9. & 1 & 1 & 4.5 & .4 & 4 & 4.5 & \\
\hline & - & 2.1 & 1. & 6.3 & 10.5 & 9 & 34.6 & 12.7 & 6.8 & 0.4 & - & \\
\hline & 2.0 & & 4.0 & 6.0 & 20.0 & 0 & .0 & & 4.0 & & .0 & \\
\hline
\end{tabular}

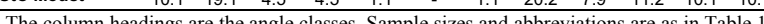

Table 4. Frequency distribution of $\log 10$-transformed cutmark lengths in the

\begin{tabular}{|c|c|c|c|c|c|c|c|c|c|c|}
\hline & $\begin{array}{l}-2.5- \\
-2.17 \\
\end{array}$ & $\begin{array}{r}-2.17- \\
-1.84 \\
\end{array}$ & $\begin{array}{r}-1.84- \\
-1.51 \\
\end{array}$ & $\begin{array}{r}-1.51- \\
-1.18 \\
\end{array}$ & $\begin{array}{r}-1.18- \\
-0.85 \\
\end{array}$ & $\begin{array}{r}-0.85- \\
-0.52 \\
\end{array}$ & $\begin{array}{c}-0.52- \\
-0.19 \\
\end{array}$ & $\begin{array}{r}-0.19- \\
0.14 \\
\end{array}$ & $\begin{array}{r}0.14- \\
0.47 \\
\end{array}$ & $\begin{array}{r}0.47- \\
0.80 \\
\end{array}$ \\
\hline lesEgl LMag & - & - & - & 0.3 & 5.4 & 31.4 & 35.8 & 20.9 & 5.6 & 0.6 \\
\hline RdB E LMag & - & - & - & 0.6 & 14.4 & 43.7 & 21.5 & 14.3 & 4.7 & 0.8 \\
\hline Solut LMag & - & - & - & - & - & 85.7 & 14.3 & - & - & \\
\hline MNeuf MMag & & & & - & 8.1 & 44.7 & 35.5 & 10.0 & 1.4 & 0.3 \\
\hline Le Flag MMag & - & - & 0.7 & 12.8 & 40.3 & 23.1 & 15.4 & 7.0 & 0.7 & \\
\hline St-Ger1 EMag & - & 0.1 & 0.1 & 0.2 & 11.3 & 36.5 & 27.6 & 18.4 & 5.6 & 0.2 \\
\hline $\begin{array}{l}\text { St-Ger3-4 } \\
\text { EMag }\end{array}$ & - & & & - & 5.8 & 28.5 & 33.1 & 24.1 & 7.9 & 0.6 \\
\hline RdB F2 Bad & - & - & 0.1 & 1.3 & 12.8 & 35.8 & 22.8 & 14.6 & 11.9 & 0.6 \\
\hline CuzV Bad & & 0.1 & 1.4 & 5.0 & 18.8 & 35.8 & 26 & 10.4 & 2.3 & 0.1 \\
\hline CuzV Sol & & & & 2.2 & 13.9 & 33.6 & 33.9 & 12.0 & 4.4 & \\
\hline ComSau Sol & - & - & 0.1 & 1.7 & 15.3 & 36.9 & 28.9 & 13.1 & 3.8 & 0.1 \\
\hline Pataud Gr & & 0.2 & & 1.4 & 21.8 & 51.4 & 23 & 1.9 & 0.3 & \\
\hline StC EvAuri & - & & - & - & 1.0 & 25.0 & 50.0 & 18.8 & 4.2 & 1.0 \\
\hline StC MAuri & - & - & - & - & 1.7 & 28.9 & 50.5 & 14.3 & 4.4 & 0.3 \\
\hline Ist EAuri & - & 0.6 & 1.5 & 12.9 & 34.1 & 35.8 & 12.5 & 2.4 & 0.2 & \\
\hline Abei EAuri & 0.1 & 0.8 & 4.2 & 11.7 & 34.5 & 33.1 & 10.9 & 4.7 & - & - \\
\hline QuAv EAuri & 0.1 & 0.4 & 1.9 & 12.9 & 37.1 & 35.3 & 10.3 & 2.0 & 0.2 & - \\
\hline Cellier EAuri & - & - & - & - & 17.2 & 27.6 & 41.4 & 13.8 & - & - \\
\hline Cast EAuri & - & 0.3 & 1.0 & 3.5 & 10.0 & 40.4 & 34.3 & 9.5 & 1.0 & \\
\hline RdC EAuri & & 0.2 & 0.7 & 4.9 & 23.2 & 43.7 & 25.1 & 2.1 & - & \\
\hline Ist ProtA & 0.9 & 0.5 & 9.8 & 20.1 & 22.4 & 25.7 & 14.5 & 5.1 & 0.9 & \\
\hline Abei ProtA & & & 1.7 & - & 6.8 & 39 & 44.1 & 8.5 & - & \\
\hline GrRen ProtA & - & - & - & - & 1.2 & 2.4 & 54.1 & 36.5 & 5.9 & \\
\hline GrRen Chât & - & - & - & - & 6.3 & 24.1 & 53.6 & 16.1 & - & \\
\hline RdC Chât & - & 0.4 & 1.3 & 7.2 & 31.6 & 36.7 & 18.6 & 4.2 & - & \\
\hline QuAv Chât & & & & 8.0 & 52.0 & 30.0 & 6.0 & 4.0 & - & \\
\hline StC Moust & - & - & - & - & - & 10.1 & 65.2 & 12.4 & 12.4 & - \\
\hline
\end{tabular}

${ }^{\mathrm{a}}$ The column headings are the size classes. Sample sizes are as in Table 1.
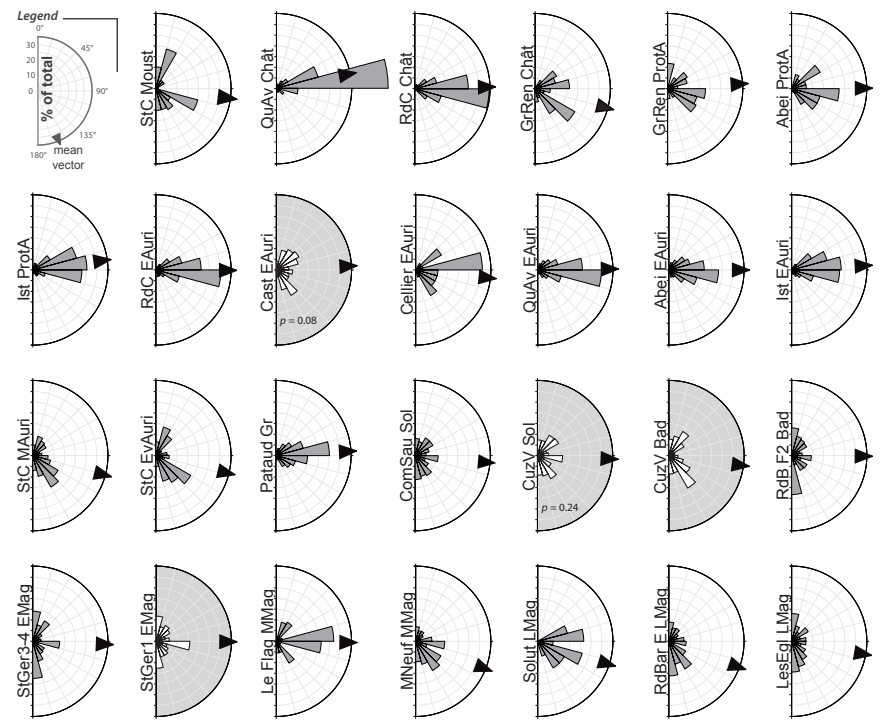

Figure 8. Rose diagrams showing the distributions of cutmark orientations in the archaeological sample. The arrows show the mean angle ('mean vector') for each of the samples. Diagrams showing a unimodal distribution (identified by a white background) are distinguished from those consistent with a bimodal axial distribution (identified by a gray background). All the distributions are statistically significant, except for two assemblages (Cast EAuri and CuzV Sol). Abbreviations are as listed in Table 1. The raw measurement data are available in the SOM, Table 2.
Table 5. Test of preferential orientation of cutmarks. ${ }^{a}$

\begin{tabular}{|c|c|c|c|c|}
\hline & Ncut & $L$ & $L_{2}$ & $p$-value \\
\hline \multicolumn{5}{|l|}{ Late Magdalenian } \\
\hline lesEgl LMag & 628 & 21.6 & 12.9 & $<0.0001$ \\
\hline RdB E LMag & 707 & 23.8 & 11.5 & $<0.0001$ \\
\hline Solut LMag & 14 & 56.4 & 15.9 & $<0.02$ \\
\hline \multicolumn{5}{|l|}{ Middle Magdalenian } \\
\hline MNeuf MMag & 369 & 26.9 & 3.7 & $<0.0001$ \\
\hline Le Flag MMag & 273 & 27.6 & 26.6 & $<0.0001$ \\
\hline \multicolumn{5}{|l|}{ Early Magdalenian } \\
\hline St-Ger1 EMag & 2321 & 6.3 & 16.9 & $<0.001$ \\
\hline St-Ger3-4 EMag & 694 & 24.5 & 18.9 & $<0.0001$ \\
\hline \multicolumn{5}{|l|}{ Badegoulian } \\
\hline RdB F2 Bad & 971 & 21.0 & 14.1 & $<0.0001$ \\
\hline CuzV Bad & 734 & 20.8 & 25.1 & $<0.0001$ \\
\hline \multicolumn{5}{|l|}{ Solutrean } \\
\hline CuzV Sol & 274 & 7.2 & 10.0 & $=0.24$ \\
\hline ComSau Sol & 1429 & 8.5 & 8.1 & $<0.0001$ \\
\hline \multicolumn{5}{|l|}{ Gravettian } \\
\hline Pataud Gr & 578 & 48.9 & 15.2 & $<0.0001$ \\
\hline \multicolumn{5}{|l|}{ Evolved Aurignacian } \\
\hline StC EvAuri & 96 & 28.4 & 23.8 & $<0.001$ \\
\hline \multicolumn{5}{|l|}{ Middle Aurignacian } \\
\hline StC MAuri & 769 & 22.0 & 20.6 & $<0.0001$ \\
\hline \multicolumn{5}{|l|}{ Early Aurignacian } \\
\hline Ist EAuri & 945 & 62.9 & 26.3 & $<0.0001$ \\
\hline Abei EAuri & 1100 & 48.9 & 17.6 & $<0.0001$ \\
\hline QuAv EAuri & 5824 & 59.7 & 29.9 & $<0.0001$ \\
\hline Cellier EAuri & 29 & 48.8 & 20.8 & $<0.001$ \\
\hline Cast EAuri & 621 & 6.3 & 21.1 & $=0.08$ \\
\hline RdC EAuri & 813 & 63.3 & 32.6 & $<0.0001$ \\
\hline \multicolumn{5}{|l|}{ Protoaurignacian } \\
\hline Ist ProtA & 214 & 65.5 & 35.4 & $<0.0001$ \\
\hline Abei ProtA & 59 & 41.3 & 18.4 & $<0.0001$ \\
\hline GrRen ProtA & 85 & 25.7 & 13.1 & $<0.005$ \\
\hline \multicolumn{5}{|l|}{ Châtelperronian } \\
\hline GrRen Chât & 112 & 32.0 & 20.0 & $<0.0001$ \\
\hline RdC Chât & 237 & 76.0 & 42.1 & $<0.0001$ \\
\hline QuAv Chât & 50 & 79.5 & 60.8 & $<0.0001$ \\
\hline \multicolumn{5}{|l|}{ Mousterian } \\
\hline StC Moust & 89 & 30.6 & 24.2 & $<0.001$ \\
\hline $\begin{array}{l}L \text { measures whethe } \\
\text { von Mises distributi } \\
\text { distribution), wherea } \\
\text { match with a bimoda } \\
\text { showing } L_{2}>L \text { are } \\
\text { calculated using the } \\
\text { as given in Table } 1 \text {. }\end{array}$ & $\begin{array}{l}e \text { ass } \\
\text { the }\end{array}$ & $\begin{array}{l}\text { mblag } \\
\text { rcular }\end{array}$ & $\begin{array}{l}\text { how } \\
\text { divale }\end{array}$ & $\begin{array}{l}\text { d fit with a } \\
\text { r a norma } \\
\text { is a better } \\
\text { ssemblages } \\
\text { alues were } \\
\text { breviations }\end{array}$ \\
\hline
\end{tabular}

Numérotation de l'auteur (non similaire à la publication) : 13 
In a manner reminiscent of the Evenki sample, several early archaeological assemblages show a clear unimodal distribution of cutmark orientations, with orientations indicating a high representation of transverse and oblique cutmarks (Fig. 8). Moreover, the $L$ values for these assemblages are often high and statistically significant (Table 5). This pattern contrasts with the more flattened distributions observed in the Solutrean and Magdalenian sample, which are strongly reminiscent of those seen in species processed for biltong. When examined from a diachronic perspective, $L$ values are generally stronger in the earlier (Mousterian to Gravettian) than the later (Solutrean and Magdalenian) assemblages (Fig. 9). There are, however, some exceptions to the diachronic trend in $L$ values. First, not all early assemblages yield high $L$ values. For instance, although sample sizes are sometimes small, the assemblages from Saint-Césaire and Grotte du Renne have $L$ values that are more typical of those seen in later assemblages. Moreover, it is interesting to note that among the four assemblages that appear to fit an axial bimodal distribution (i.e., with $L_{2}>L$ ), one (Castanet, in light gray in Figs. 8-9) is dated to the Early Aurignacian. While the result is not statistically significant, the distribution of cutmark orientations at Castanet is visibly different from that recorded in coeval assemblages. Among the recent assemblages, Le Flageolet indicates a clear tendency toward a unimodal distribution, despite a low $L$ value. As noted above, Solutré departs from the general pattern seen among the late Upper Paleolithic assemblages. The small sample size of cutmarks for this site $(\mathrm{Ncut}=14)$ may explain this discrepancy.

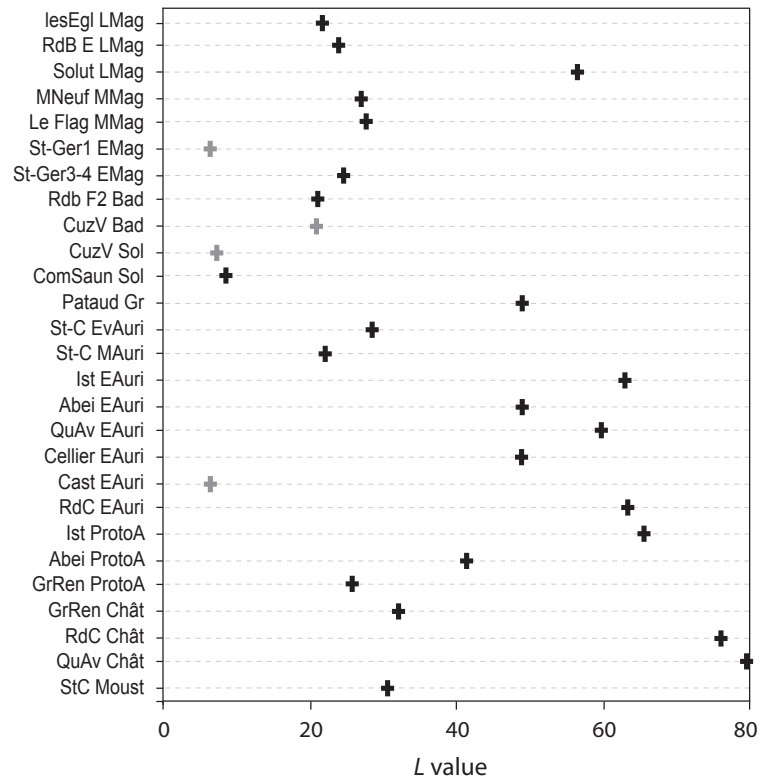

Figure 9. Curray's $L$ values in the archaeological sample. In general, the higher the $L$ value, the stronger the fit with a non-random distribution of cutmark orientations. Symbols in gray identify assemblages consistent with a bimodal axial distribution. Abbreviations are as listed in Table 1. The raw measurement data are available in the SOM, Table 2.

Figure 10a gives the proportions of longitudinal, transverse, and oblique cutmarks in the archaeological sample. Most assemblages are dominated by oblique cutmarks. More interesting is the general tendency in the dataset for longitudinal cutmarks to increase, and transverse cutmarks to decrease, in relative frequency from the early to the late Upper Paleolithic. A Cochran's test for linear trend confirms the statistical significance of both patterns (longitudinal versus all other orientations: $\chi^{2}$ trend $=1517.4, p<0.001$; transverse versus all other orientations: $\chi_{\text {trend }}^{2}=1141.1, p<0.001$ ). In fact, the percentages of longitudinal cutmarks in the Solutrean and Magdalenian assemblages align relatively well with the range of values recorded in the South African dataset, our model for meat filleting. The same observation holds for the transverse cutmarks, which means that the distribution of cutmark orientations in the late Upper Paleolithic sample is very similar to that of the South African model, and unlike that seen for the Evenki. In our sample, the Châtelperronian layers of Roc-de-Combe and La Quina aval are the only two assemblages that may match the Evenki model for boiled unboned meat. However, for reasons pointed out below, the patterns observed at these sites are probably more parsimoniously explained by simple defleshing. 
a)

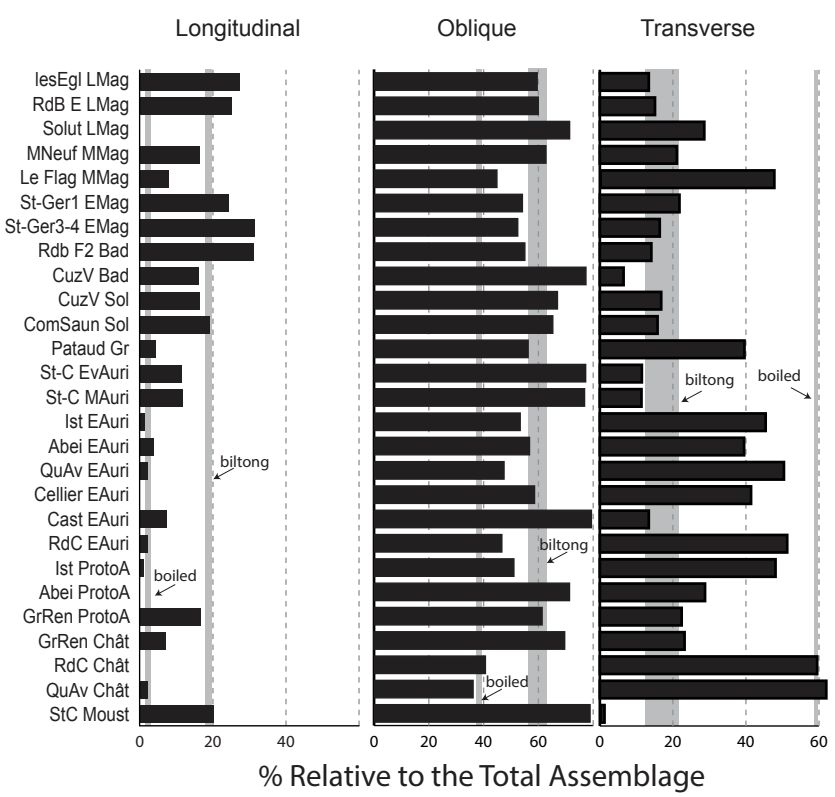

b) Cutmark length (log10-transformed)

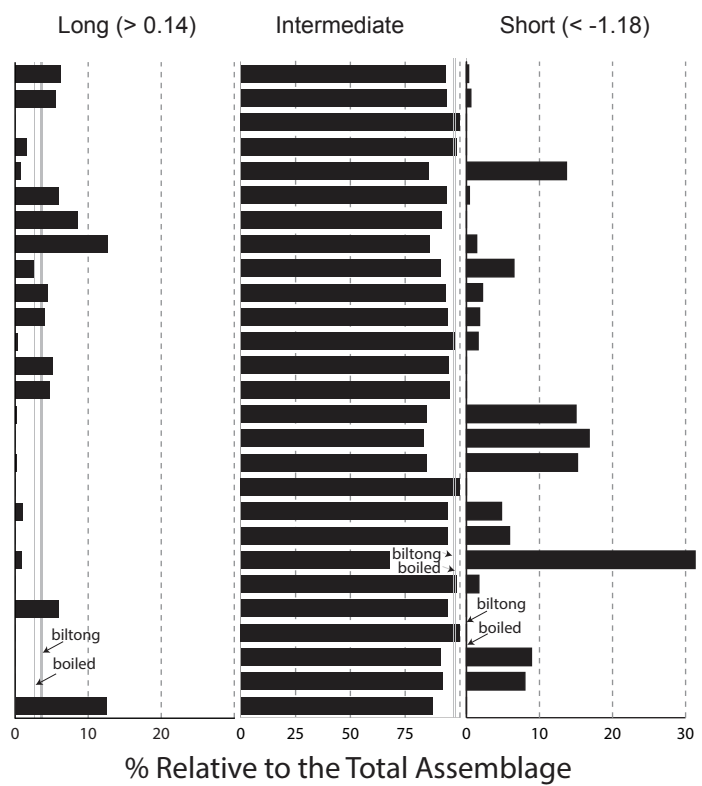

Figure 10. Quantitative cutmark data in the archaeological sample: a) percentages of longitudinal, oblique, and transverse cutmarks, and b) percentages of long, intermediate, and short cutmarks. Percentages were calculated relative to the total assemblage. The gray shaded areas simply reproduce the range of actualistic values for boiled meat and biltong production in Figure 4. Abbreviations are as listed in Table 1. The raw measurement data are available in SOM, Table 2.

Concerning the $\log 10$-transformed length measurements, we note that there are only relatively minor fluctuations in the representation of cutmarks of intermediate length, the category that is best represented in the sample (Fig. 10b). Long and short cutmarks display opposite patterns; long cutmarks are common in late assemblages, whereas short cutmarks tend to occur at higher frequencies in early Upper Paleolithic assemblages (long versus all other lengths: $\chi^{2}$ trend $=372.2, p<0.001$; short versus all other lengths: $\chi^{2}$ trend $=613.1, p<0.001$ ). With respect to the former of these trends, it is important to emphasize that the relative abundance of long cutmarks in the late Paleolithic assemblages is as high - and regularly higher-than the corresponding values in the two actualistic models that we used. Again, some assemblages deviate from these trends. The Mousterian assemblage from Saint-Césaire and the Protoaurignacian assemblage from Grotte du Renne present patterns that fit better with the Solutrean-Magdalenian than with the earlier assemblages, whereas the opposite is true of Le Flageolet and Solutré. Interestingly, short cutmarks are common in the archaeological dataset - especially in the early Upper Palaeolithic assemblages - while these are absent in the actualistic samples. The use of long metal blades by the Evenki and South African butchers possibly explains the lack of short cutmarks in the actualistic samples.

To better understand variations in cutmark types within the archaeological sample, Figure 11 compares data separately for the four categories of long bones. Generally, cutmarks are longer in the stylopodium than the zeugopodium. If we consider only those assemblages in which all four long bones have an Ncut larger than 30, this pattern holds in 13 out of 15 cases in the hindleg and in all 15 cases in the foreleg. These high frequencies are noteworthy given that they are significantly different from chance (Table 6). The data also suggest that cutmarks are shorter during the Early Aurignacian than in older or younger time periods, with the exception of the Magdalenian sample from Le Flageolet. An intriguing observation is the large spread of values in the Protoaurignacian of Isturitz (Fig. 11), an assemblage with a reasonably large sample size (Ncut $=214)$. There is no simple explanation for this outlier at the moment. 


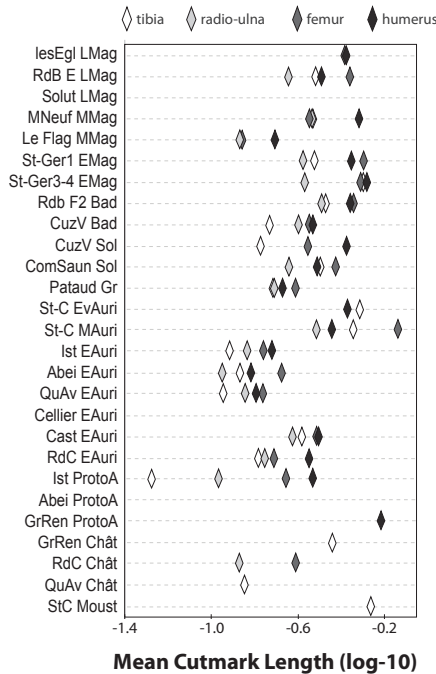

Figure 11. Mean cutmark (log10-transformed) length by element in the archaeological sample. Sample sizes $<30$ Ncut excluded. Abbreviations are as listed in Table 1. The raw measurement data are available in the SOM, Table 2.
Table 6. Chi-square goodness-of-fit tests for mean $\log 10$ transformed length measurements in the hindleg versus the foreleg. ${ }^{a}$

\begin{tabular}{lcc}
\hline & $\begin{array}{c}\text { Hindleg: } \\
\text { femur }>\text { tibia }\end{array}$ & $\begin{array}{c}\text { Foreleg: } \\
\text { humerus }>\text { radio-ulna }\end{array}$ \\
\hline $\begin{array}{l}\text { Observed proportion } \\
\text { Expected proportion }\end{array}$ & $13 / 15$ & $15 / 15$ \\
& $7.5 / 15$ & $7.5 / 15$ \\
$\chi^{2}$ results & $8.07, p<0.01$ & $15.00, p<0.001$ \\
\hline
\end{tabular}

a The tests examine whether, in the archaeological sample, mean cutmark lengths for the stylopodium (femur or humerus) tend to be larger than that for the zeugopodium (tibia or radio-ulna). The null model assumes a random distribution of cutmark lengths between bones. Only assemblages $(N=15)$ with sample sizes $>30$ for each individual long bone are included.

The analysis of the results for the individual long bones in the archaeological sample confirms trends inferred on the basis of the whole sample of cutmarks. Transverse and longitudinal cutmarks follow opposite trends through time. While transverse cutmarks are common in the early assemblages (Fig. 12a), values for longitudinal cutmarks are generally larger in the later assemblages (Fig. 12b). Despite this trend, the rank of the four long bones seems to vary more or less randomly within and between time periods. In contrast, $\log 10$ transformed length measurements provide evidence for a time-transgressive increase in the representation of long cutmarks along with a decline in that of short cutmarks (Fig. 13a-b). The short cutmarks sometimes attest to a wide distribution of values, as is the case at Isturitz, Les Abeilles, and Le Flageolet.

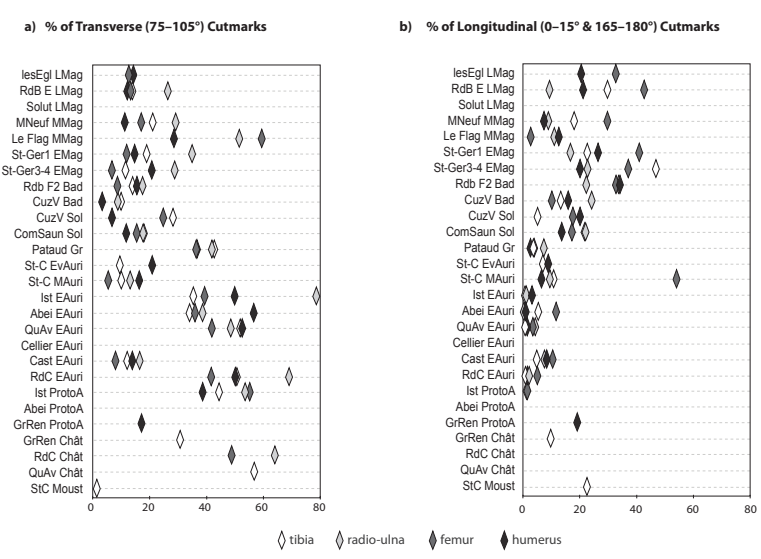

Figure 12. Percentages of a) transverse and b) longitudinal cutmarks by element and assemblage in the archaeological sample. Percentages were calculated relative to the total sample for the selected element and assemblage. Abbreviations are as listed in Table 1. The raw measurement data are available in the SOM, Table 2.

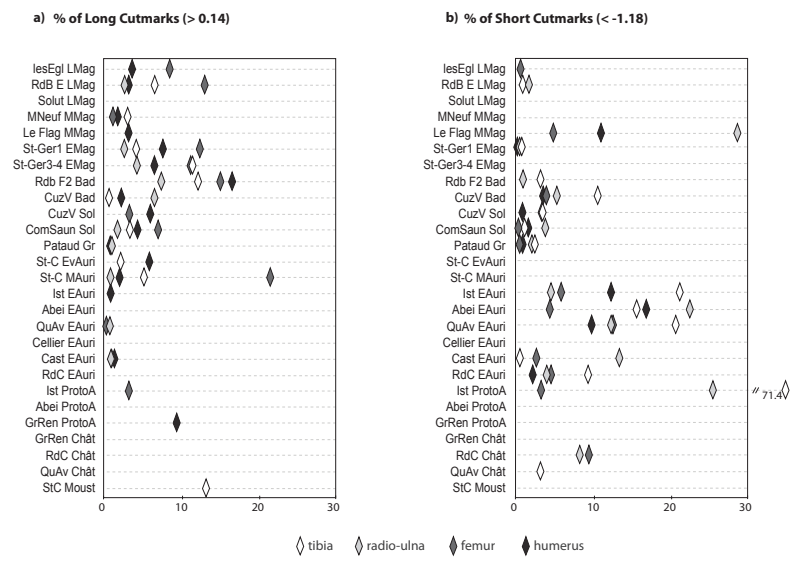

Figure 13. Percentages of a) long and b) short cutmarks by element and assemblage in the archaeological sample. Percentages were calculated relative to the total sample for the selected element and assemblage. Abbreviations are as listed in Table 1. The raw measurement data are available in the SOM, Table 2.

Numérotation de l'auteur (non similaire à la publication) : 16 
Because the actualistic literature suggests that meat filleting is closely associated with the occurrence of long longitudinal cutmarks, the relative abundance of cutmarks possessing both of these characteristics was computed for each assemblage. Figure 14 reveals that these cutmarks are more common in the later than the earlier Paleolithic, a trend that is statistically significant $\left(\chi_{\text {trend }}^{2}=389.8, p<0.001\right.$; long longitudinal versus all other cutmarks). However, the occupations from Saint-Césaire and the Protoaurignacian assemblage from Grotte du Renne indicate patterns that fit better with the more recent (Solutrean-Magdalenian) assemblages.

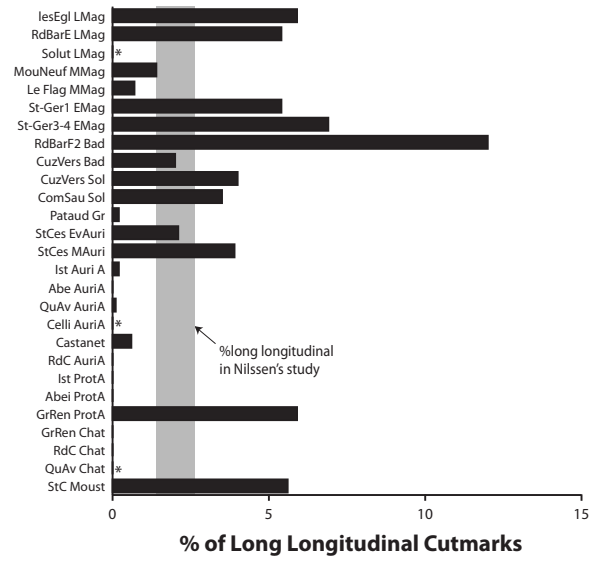

Figure 14. Percentages of cutmarks that are both long and longitudinal in the archaeological sample. Percentages were calculated relative to the total sample for the selected element and assemblage. The range of values (vertical gray line) given for Nilssen's study simply reproduces the values presented in Figure 4. Assemblages with an asterisk have total Ncut $<30$. Abbreviations are as listed in Table 1. The raw measurement data are available in the SOM, Tables 1 and 2.

Several lines of evidence suggest that this temporal trend is closely related to meat removal rather than to other activities, such as the removal of the periosteum (as reported by Costamagno and David, 2009, see above). Because this last practice was documented in a very specific context (the extensive removal of periosteal tissue prior to fracturing the bone with an axe), these marks are unlikely to be represented in our sample. The fact that long longitudinal cutmarks prevail on the meaty bone portions of the long bones (Fig. 15) and rarely occur in zones where meat is thin or absent (e.g., the distal tibia and distal radio-ulna) yields support for this view. Moreover, long longitudinal cutmarks are frequent on the ulna, an element that lacks a substantial marrow cavity. Other activities can also largely be ruled out. As pointed out earlier with respect to the overall distribution of the cutmarks, long longitudinal cutmarks in the assemblages are not consistent with disarticulation because they rarely occur near the extremities of the long bones. Furthermore, they tend to occur at higher frequencies on the meatier femur and humerus than on the tibia and radio-ulna (Fig. 15). For these reasons, the majority of the long longitudinal cutmarks documented in our study can probably be safely attributed to meat removal and, according to the actualistic data available, to filleting.

Anatomical profiles are sometimes used as a line of evidence to investigate meat drying, with the presumption that the meatiest bones should dominate in the archaeological assemblage if it was a major activity at the site. For instance, the assemblages examined in the present study may be compared with a wide range of utility indices to see whether they show strong correlations with the Meat Drying Index (Friesen, 2001). One potential issue with this approach is that it assumes that bones-not just meat-are selected and treated as a function of their associated dried meat value. A related issue is that this approach also assumes that skeletal abundances have not been modified after meat was removed. However, as pointed out by Bartram (1993), this need not be given that meat and bones may frequently go on separate trajectories in the real world (e.g., bones may be discarded during primary butchery or stored as raw material). In agreement with this view, two studies that included many of the assemblages examined here showed that bones were generally transported to the sites as a function of their unsaturated marrow content, and this despite extensive evidence for meat removal (Morin and Ready, 2013; Soulier 2013). Moreover, the assemblages analyzed here attest to complex patterns of carcass treatment, including systematic marrow cracking and the use of bones as tool blanks and as fuel (see references in Table 1). In sum, given the nature of the sites included in this study and the effects of transport and bone processing decisions on assemblage composition, anatomical profiles are unlikely to be helpful in the present case. 


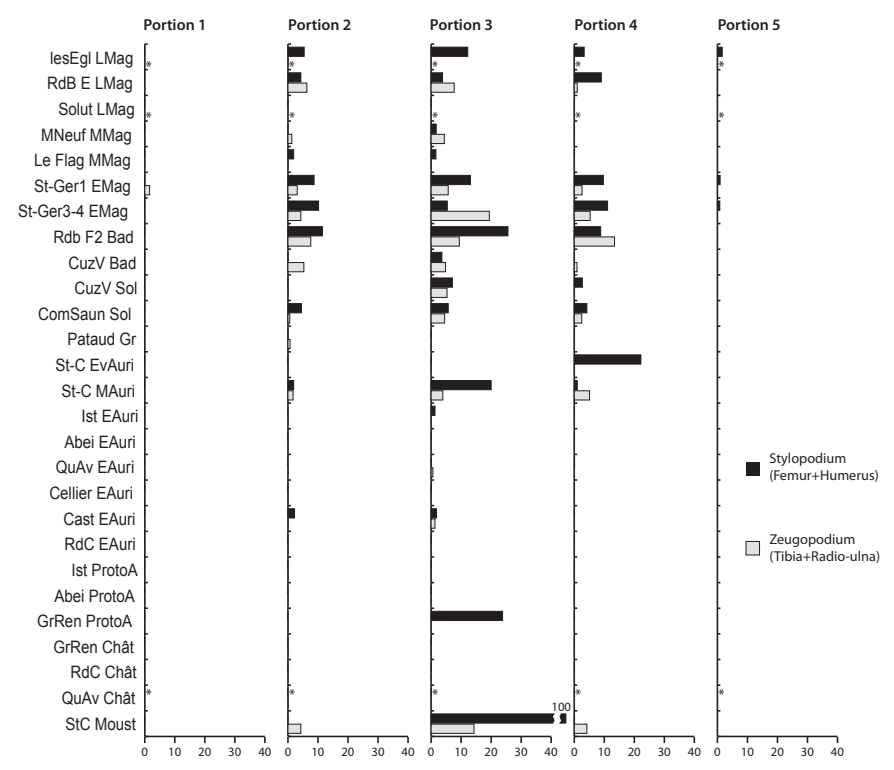

Figure 15. Percentage of long longitudinal cutmark by assemblage and bone portion in the stylopodium and zeugopodium. An asterisk means that there are no cutmarks for the relevant bone portion. Abbreviations are as listed in Table 1. The raw measurement data are available in the SOM, Table 2.

\section{Discussion and Conclusion}

Comparisons between cutmark data from controlled butcheries and 27 assemblages from the Late Pleistocene of France highlight several important findings. Whether boiling is documented in the archaeological sample is difficult to assess due to the very low representation of long bone extremities in the assemblages we examined. Indeed, according to Abe (2005), boiling unboned meat results in few cutmarks, the majority of which are found near the joints. The fact that many early Upper Palaeolithic assemblages show relatively high percentages of cutmarks, sometimes associated with multiple, deep strokes (Soulier, 2013), is not consistent with this practice. In fact, these assemblages most probably reflect simple defleshing without boiling. Additional actualistic data would permit more definitive conclusions on this issue.

Our review of the actualistic literature indicates that meat filleting is frequently associated with long longitudinal cutmarks. These cutmarks reflect the need to remove long pieces of meat, sometimes extending over more than a single bone (Binford, 1978; Nilssen, 2000; Odgaard, 2007; Pasda and Odgaard, 2011). These large pieces of meat are normally subsequently cut into strips for drying, for instance through smoking, sun or wind drying. Importantly, the evidence also suggests that long longitudinal cutmarks are rarely observed on meaty bones in other behavioral contexts. Obviously, caution is advised here, as we cannot exclude the possibility that other, currently undescribed, processing activities produced long longitudinal cutmarks unrelated to filleting. Nonetheless, the high frequency of longitudinal cutmarks in our sample is consistent with controlled data on meat filleting activities, and supports a hypothesis of meat preservation in the Paleolithic.

In the archaeological dataset, long longitudinal cutmarks are statistically more common in the Solutrean and Magdalenian assemblages than in those attributed to the early Upper Paleolithic. Although we could not control for all potentially confounding variables, this pattern seems robust as it is documented in a large number of assemblages. Moreover, the observation that, in our sample, cutmarks are consistently longer on the meatier elements (humerus and femur) than on the less meaty ones (radio-ulna and tibia) indicates that this trend is not the result of an artifact in methods of illustration between archaeologists working on different time periods. Moreover, this pattern seems to occur regardless of skeletal element or species. Assuming that the actualistic studies examined here are representative of the range of activities in which long longitudinal cutmarks are produced, these results suggest that techniques that enhance the preservation of meat were commonly employed in the second half of the Upper Paleolithic. 
Importantly, cutmarks recorded in some early assemblages are likewise consistent with filleting. For instance, the Mousterian assemblage from Saint-Césaire and the Protoaurignacian assemblage from Grotte du Renne both show 'high' percentages of long longitudinal cutmarks and distributions of cutmark lengths and orientations that are similar to those seen in late Upper Palaeolithic faunas. The strength of this conclusion is, however, weakened by the small sample size of the two assemblages (Ncut $=89$, Ncut $=85$, respectively). Nonetheless, the fact that long longitudinal cutmarks have also been observed in other, and sometimes much earlier, Middle Paleolithic contexts, for instance at Crvena Stijena in Montenegro (Morin, pers. obs., 2014), Les Pradelles layer 4a (Soulier, pers. obs., 2013) and Espagnac (Brugal, 2001) in France, and Abric Romaní, level I (Vallverdú et al., 2005) in Spain, suggests that strategies aimed at meat preservation have potentially relatively deep roots in the Pleistocene. If correct, these results suggest that the practice of meat filleting simply rose or varied in relative frequency during the course of the Late Pleistocene.

The importance of techniques of meat preservation to the subsistence of historic and subactual foragers cannot be understated, given that in lean seasons certain products such as dried meat or smoked meat represented - and, in certain areas, continue to represent - a major source of dietary energy (Stefansson, 1913, 1956; Jenness, 1922; Lantis, 1946; Sinclair, 1953; Binford, 1978; Chatters, 1987; Stopp, 2002; Keith, 2004; Batal et al., 2005; Odgaard, 2007; Vaté and Beyries, 2007; Pasda, 2013). Although most techniques of meat preservation are time-demanding and require extensive knowledge (e.g., Binford, 1978; Bartram, 1993; Odgaard, 2007; Pasda and Odgaard, 2011), they have substantial advantages. For instance, meat drying significantly reduces transport costs and greatly facilitates storage through a reduction in weight (on the order of $29 \%$ according to Bartram, 1993) and volume. Importantly, these changes occur without an appreciable impact on nutritional properties and energy value (Heinz and Hautzinger, 2007). Moreover, dried meat can be mixed with fat to enhance taste and increase its energetic content (e.g., Sinclair, 1953; Stefansson, 1956; Binford, 1978; Hungry Wolf, 1980; Jarvenpa and Brumbach, 1983). Second, because reduced moisture content impedes bacterial growth, dried meat can be conserved over long periods of time (up to several years in favorable environments; Stefansson, 1956; Malaurie, 1990) and is often saved for times of food insecurity (Binford, 1978; Stopp, 2002). Given that both of these goals entail a concern for anticipated needs from the part of the forager, strategies of meat preservation imply the capacity for 'temporal displacement', that is, the ability to think beyond the 'here-and-now' (Whallon, 1989; Botha, 2008; Roebroeks and Verpoorte, 2009). For these reasons, the study of meat preservation has the potential to shed much light on the logistical organization and cognitive evolution of hominins.

The fact that some Mousterian assemblages seem to show frequent long longitudinal cutmarks possibly indicates that meat drying was a component of the behavioral repertoire of late Neandertals, a finding that would support the idea that the capacity for planning ahead was already inbuilt in these populations (e.g., Geneste, 1985; Roebroeks et al., 1988; Féblot-Augustins, 1993; Costamagno et al., 2006; Delagnes and Rendu, 2011; Rendu et al., 2012). Another interpretation is that the changes recorded in our sample may simply reflect a shift in the frequency with which populations coped with similar problems, or alternately, they may denote differences in the logistical organization of the hominin groups. Although more data are needed for the late Aurignacian and the Gravettian, it is of significance to note that the increase in the relative frequency of long longitudinal cutmarks observed in our sample roughly coincided with the Last Glacial Maximum, an episode marked by dietary intensification and diversification in the study area (e.g., Cochard, 2004; Langlais et al., 2012). Because this episode of intensification is generally interpreted as a response to severe imbalances between population densities and resource availability, it is plausible that food shortage led to an increased use of preserved meat during the Last Glacial Maximum. In contrast, goals during the Middle and early Upper Paleolithic perhaps more frequently involved concerns for reducing transport costs, with storage being a less common practice. Whether these changes attest to logistical and dietary adaptations to new demographic challenges will remain to be determined. In the meanwhile, the data are at least suggestive of appreciable changes in the subsistence organization of the local populations.

Overall, the above results show that detailed analyses of cutmarks provide a powerful tool for exploring changing uses of animal resources by hominin groups. Although it is a time-consuming task, we strongly encourage archaeozoologists to produce illustration of cutmarks, as these can yield valuable insights on carcass processing behavior. In this respect, additional well-controlled actualistic studies would contribute greatly to our understanding of past human subsistence. 


\section{Acknowledgments}

This study was funded by a SSHRC Insight Research Grant (awarded to EM) and by the French Ministry of Higher Education and Research and the UMR 5608-TRACES lab, CNRS (MCS). We would like to express our gratitude to James Conolly, Sandrine Costamagno, Emmanuel Discamps, Arnaud Lenoble, and Peter Nilssen for help during the analysis of the data. We extend our gratitude to François Bachellerie, Jean-Guillaume Bordes, Brad Gravina, Alexandre Michel, and our other collaborators for the work carried out on the cultural stratigraphy at Saint-Césaire (Projet d'APP, "La Roche à Pierrot, St-Césaire [fouilles François Lévêque]: La séquence paléolithique supérieur"). Lastly, we would like to thank two anonymous reviewers and an associate editor for their valuable comments and suggestions.

\section{References}

Abe, Y., 2005. Hunting and butchering patterns of the Evenki in the Northern Transbaikalia Russia. Ph.D. Dissertation, Stony Brook University.

Abe, Y., Marean, C., Nilssen, P.J., Assefa, Z., Stone, E., 2002. The analysis of cutmarks on archaeofauna: a review and critique of quantification procedures, and a new image-analysis GIS approach. Am. Antiq. 67, 643-663.

Andrews, P., 1995. Experiments in taphonomy. J. Archaeol. Sci. 22, 147-153.

Andrews, P., Cook, J., 1985. Natural modifications to bones in a temperate setting. Man 20, 675-691.

Bartram, L.E., 1993. Perspectives on skeletal part profiles and utility curves from eastern Kalahari ethnoarchaeology. In: Hudson, J. (Ed.), From bones to behavior: ethnoarchaeological and experimental contributions to the interpretation of faunal remains. Southern Illinois University, Center for Archaeological Investigation, Carbondale, pp. 115-155.

Batal, M., Gray-Donald, K., Kuhnlein, H.V., Receveur, O., 2005. Estimation of traditional food intake in indigenous communities in Denendeh and the Yukon. Int. J. Circumpol. Health 64, 46-54.

Batschelet, E., 1981. Circular statistics in biology. Academic Press, London.

Behrensmeyer, A.K., Gordon, K.D., Yanagi, G.T., 1986. Trampling as a cause of bone surface damage and pseudo-cutmarks. Nature 319, 768-771.

Bertran, P., Texier, J.-P., 1995. Fabric analysis: application to Paleolithic sites. J. Archaeol. Sci. 22, 521-535.

Bez, J.-F., 1995. Une expérience de découpe bouchère pratiquée au silex: aspects anatomiques. Préhistoire Anthropologie Méditerranéennes 4, 41-50.

Bickerton, D., 2009. Adam's tongue. Hill and Wang, New York.

Binford, L.R., 1978. Nunamiut ethnoarchaeology. Academic Press, New York.

Binford, L.R., 1981. Bones: ancient men and modern myths. Academic Press, New York.

Binford, L.R., 1984. Faunal remains from Klasies River Mouth. Academic Press, New York.

Binford, L.R., 1988. Étude taphonomique des restes fauniques de la Grotte Vaufrey, couche VIII. In: Rigaud, J.P. (Ed.), La Grotte Vaufrey: paléoenvironnement, chronologie, activités humaines. Mém. Soc. Préhist. Fr., Paris, pp. 535-564.

Botha, R., 2008. Prehistoric shell beads as a window on language evolution. Lang. Commun. 28, $197-212$.

Brugal, J.-P., 2001. Les assemblages fauniques: paléoenvironnement, taphonomie et archéozoologie. In: Jaubert, J. (Ed.), Un site moustérien de type Quina dans la vallée du Célé. Pailhès à Espagnac-Sainte-Eulalie (Lot). Gallia Préhist. 43, Paris, pp. 33-52.

Bunn, H.T., Kroll, E.M., 1988. Reply to L.R. Binford's "Fact and fiction about the FLK Zinjanthropus floor: data, arguments, and interpretations." Curr. Anthropol. 29, 135-149.

Cannon, M., 2001. Archaeofaunal relative abundance, sample size and statistical methods. J. Archaeol. Sci. 28, $185-195$.

Cardozo, N., Allmendinger, R., 2013. Spherical projections with OSXStereonet. Comput. Geosci. 51, $193-205$.

Castel, J.-C., 1999. Comportements de subsistance au Solutréen et au Badegoulien d'après les faunes de CombeSaunière (Dordogne) et du Cuzoul de Vers (Lot). Ph.D. Dissertation, Université de Bordeaux I.

Castel, J.-C., 2003. Économie de chasse et d'exploitation de l'animal au Cuzoul de Vers (Lot) au Solutréen et au Badegoulien. Bull. Soc. Préhist. Fr. 100, 45-56.

Castel, J.-C., 2011. Archéozoologie de l'Aurignacien de l'Abri Castanet (Sergeac, Dordogne, France): les fouilles 1994-1998. Revue de Paléobiologie 30, 783-815.

Numérotation de l'auteur (non similaire à la publication) : 20 
Chatters, J.C., 1987. Hunter-gatherer adaptations and assemblage structure. J. Anthropol. Archaeol. 6, 336-375.

Cho, T., 1998. Étude archéozoologique de la faune du Périgordien supérieur: couches 2, 3 et 4 de l'abri Pataud, Les Eyzies, Dordogne: paléoécologie, taphonomie, paléoéconomie. Ph.D. Dissertation, Muséum national d'histoire naturelle.

Cochard, D., 2004. Les léporidés dans la subsistance paléolithique du sud de la France. Ph.D. Dissertation, Université de Bordeaux I.

Costamagno, S., 1999. Stratégies de chasse et fonction des sites au Magdalénien dans le sud de la France. Ph.D. Dissertation, Université de Bordeaux I.

Costamagno, S., 2012. Des stries de boucherie aux sous-systèmes techniques de transformation et de consommation des ressources animales: apport de l'approche expérimentale. HDR (Habilitation à Diriger des Recherches) thesis, Université de Bordeaux I.

Costamagno, S., David, F., 2009. Comparaison des pratiques bouchères et culinaires de différents groupes sibériens vivant de la renniculture. Archaeofauna 19, 9-25.

Costamagno, S., Meignen, L., Beauval, C., Vandermeersch, B., Maureille, B., 2006. Les Pradelles (Marillac-leFranc, France): a Mousterian reindeer hunting camp? J. Anthropol. Archaeol. 25, 466-484.

Courtin, J., Villa, P., 1982. Une expérience de piétinement. Bull. Soc. Préhist. Fr. 79, 117-123.

Curray, J., 1956. The analysis of two-dimensional orientation data. J. Geol. 64, 117-131.

David, F., Poulain, T., 2002. Les mammifères. In: Schmider, B. (Ed.), L'Aurignacien de la Grotte du Renne. Gallia Préhist., Suppl. XXXIV, CNRS Ed., pp. 51-82.

de Juana, S., Galán, A.B., Domínguez-Rodrigo, M., 2010. Taphonomic identification of cut marks made with lithic handaxes: an experimental study. J. Archaeol. Sci. 37, 1841-1850.

Delagnes, A., Rendu, W., 2011. Shifts in Neandertal mobility, technology and subsistence strategies in western France. J. Archaeol. Sci. 38, 1771-1783.

Delpech, F., Villa, P., 1993. Activités de chasse et de boucherie dans la Grotte des Églises. In: Desse, J., AudoinRouzeau, F. (Eds.), Exploitation des animaux sauvages à travers le temps. Actes des XIIIe rencontres internationales d'archéologie et d'histoire d'Antibes, IVe Colloque international de l'Homme et l'animal. APDCA, Antibes, pp. 81-102.

Deplano, S., 1994. Etude de la faune de la couche IX de l'abri du Flageolet II (Dordogne): approche taphonomique et palethnographique. Masters Thesis, Université de Paris X.

Dewbury, A.G., Russell, N., 2007. Relative frequency of butchering cutmarks produced by obsidian and flint: an experimental approach. J. Archaeol. Sci. 34, 354-357.

Dolan, J. M. Jr., 1987 The Saiga (Saiga tatarica) in captivity, with special reference to the zoological society of San Diego" In: Soma, H. (Ed.), The biology and management of capricornis and related mountain antelopes. Croom Helm, New York, pp. 41-50.

Domínguez-Rodrigo, M., 1997. Meat-eating by early hominids at the FLK 22 Zinjanthropus site, Olduvai Gorge (Tanzania): an experimental approach using cut-mark data. J. Hum. Evol. 33, 669-690.

Domínguez-Rodrigo, M., 2003. On cut marks and statistical inferences: methodological comments on Lupo and O’Connell (2002). J. Archaeol. Sci. 30, 381-386.

Domínguez-Rodrigo, M., Barba, R., 2005. A study of cut marks on small-sized carcasses and its application to the study of cut-marked bones from small mammals at the FLK Zinj site. Journal of Taphonomy 3, 121134.

Domínguez-Rodrigo, M., Yravedra, J., 2009. Why are cut mark frequencies in archaeofaunal assemblages so variable? A multivariate analysis. J. Archaeol. Sci. 36, 884-894.

Domínguez-Rodrigo, M., de Juana, S., Galán, A.B., Rodríguez, M., 2009. A new protocol to differentiate trampling marks from butchery cut marks. J. Archaeol. Sci. 36, 2643-2654.

Domínguez-Rodrigo, M., Pickering, T.R., Bunn, H.T., 2012. Experimental study of cut marks made with rocks unmodified by human flaking and its bearing on claims of $~ 3.4$-million-year old butchery evidence from Dikika, Ethiopia. J. Archaeol. Sci. 39, 205-214.

Egeland, C.P., 2003. Carcass processing intensity and cutmark creation: an experimental approach. Plains Anthropol. 48, 39-51.

Egeland, C.P., Welch, K.R., Nicholson, C.M., 2014. Experimental determinations of cutmark orientation and the reconstruction of prehistoric butchery behavior. J. Archaeol. Sci. 49, 126-133.

Fallon Morell, S., Enig, S., 2000. Guts and grease: The diet of Native Americans. Wise Traditions 4,1, 58-59.

Numérotation de l'auteur (non similaire à la publication) $: 21$ 
Féblot-Augustins, J., 1993. Mobility strategies in the late Middle Palaeolithic of Central and Western Europe: elements of stability and variability. J. Anthropol. Archaeol. 12, 211-265.

Fisher, N., 1996. Statistical analysis of circular data. Cambridge University Press, Cambridge.

Friesen, T., 2001. A zooarchaeological signature for meat storage: re-thinking the Drying Utility Index. Am. Antiq. 66, 315-331.

Galán, A.B., Domínguez-Rodrigo, M., 2013. An experimental study of the anatomical distribution of cut marks created by filleting and disarticulation on long bone ends. Archaeometry 55, 1132-1149.

Geist, V., 1998. Deer of the world: their Evolution, Behavior and Ecology. Stackpole Books, Mechanicsburg.

Geneste, J.-M., 1985. Analyse lithique d'industries moustériennes du Périgord: une approche technologique du comportement des groupes humaines au Paléolithique moyen. Ph.D. Dissertation, Université de Bordeaux I.

Gifford-Gonzalez, D., 1989. Ethnographic analogues for interpreting modified bones: some cases from East Africa. In: Bonnichsen, R., Sorg, M. (Eds.), Bone modification. Institute for quaternary studies, University of Maine, Orono, pp. 179-246.

Gifford-Gonzalez, D., Behrensmeyer, A.K., 1977. Observed formation and burial of a recent human occupation site in Kenya. Quatern. Res. 8, 245-266.

Greenfield, H.J., 1999. The origins of metallurgy: distinguishing stone from metal cut-marks on bones from archaeological sites. J. Archaeol. Sci. 26, 797-808.

Greenfield, H.J., 2006. Slicing cut marks on animal bones: diagnostics for identifying stone tool type and raw material. J. Field Archaeol. 31, 147-163.

Haynes, G., 1986. Spiral fractures and cut mark mimics in noncultural elephant bone assemblages. Current Research in the Pleistocene 3, 45-46.

Heinz, G., Hautzinger, P., 2007. Meat processing technology for small-to-medium scale producers, 2007. Food and Agriculture Organization of the United Nations. Regional Office for Asia and the Pacific, Bangkok.

Henri-Martin, L., 1907. Recherches sur l'évolution du Moustérien dans le gisement de la Quina (Charente). Vol. 1 Industrie osseuse. Schleicher Frères, Paris.

Hungry Wolf, B., 1980. The ways of my grandmothers. William Morrow \& Co, New York.

Jarvenpa, R., Brumbach, H.J., 1983. Ethnoarchaeological perspectives on an Athapaskan moose kill. Arctic 362, $174-184$.

Jenness, D., 1922. The life of the Copper Eskimos. Report of the Canadian arctic expedition 1913-18 vol. XII, 277.

Jones, P.R., 1980. Experimental butchery with modern stone tools and its relevance for Paleolithic archaeology. World Archaeol. 12, 153-165.

Keith, D., 2004. Caribou, river and ocean: Harvaqtuurmiut landscape organization and orientation. Études/Inuit/Studies 28, 39-56.

Kelsall, J.P., 1968. The migratory barren-ground caribou of Canada. Canadian Wildlife Service Monographs Series 3, The Queen's Printer, Ottawa.

Kovach, W.L., 2011. Oriana-Circular Statistics for Windows, ver. 4. Kovach Computing Services, Pentraeth, Wales, U.K.

Langlais, M., Costamagno, S., Laroulandie, V., Pétillon, J.-M., Discamps, E., Mallye, J.-B., Cochard, D., Kuntz, D., 2012. The evolution of Magdalenian societies in south-west France between 18,000 and 14,000 cal BP: changing environments, changing tool kits. Quatern. Int. 272-273, 138-149.

Lantis, M., 1946. The social culture of the Nunivak Eskimo. Transactions of the American Philosophical Society, New Series 35, 153-323.

Laroulandie, V., 2001. Les traces liées à la boucherie, à la cuisson et à la consommation d'oiseaux. Apport de l'expérimentation. In: Bourguignon, L., Ortega, I., Frère-Sautot, M.-C. (Eds.), Préhistoire et approche expérimentale. Éditions Monique Mergoil, Montagnac, pp. 97-108.

Lenoble, A., Bertran, P., 2004. Fabric of Palaeolithic levels: methods and implications for site formation processes. J. Archaeol. Sci. 31, 457-469.

Lloveras, L., Moreno García, M., Nadal, J., 2009. Butchery, cooking and human consumption marks on rabbit (Oryctolagus cuniculus) bones: an experimental study. Journal of Taphonomy 7, 179-201.

Lorvelec, O., Vigne, J.-D., 2003. Bouquetin ibérique: Capra pyrenaica Schinz, 1838. In: Pascal, M., Lorvelec, O., Vigne, J.-D., Keith, P., Clergeau, P. (Eds.), Zooarchaeology and modern human origins: Human hunting behavior during the later Pleistocene. Rapport au Ministère de l'Écologie et du Développement Durable (Direction de la Nature et des Paysages), Paris, pp. 98-100.

Numérotation de l'auteur (non similaire à la publication) : 22 
Lupo, K.D., 1994. Butchering marks and carcass acquisition strategies: distinguishing hunting from scavenging in archaeological contexts. J. Archaeol. Sci. 21, 827-837.

Lupo, K.D., O'Connell, J.F., 2002. Cut and tooth mark distributions on large animal bones: ethnoarchaeological data from the Hadza and their implications for current ideas about early human carnivory. J. Archaeol. Sci. $29,85-109$.

Lyman, R.L., 1987. Archaeofaunas and butchery studies: a taphonomic perspective. Advances in Archaeol. Method and Theory 10, 249-337.

Lyman, R.L., 1994. Vertebrate taphonomy. Cambridge University Press, Cambridge.

Lyman, R.L., 2005. Analyzing cut marks: lessons from artiodactyl remains in the northwestern United States. J. Archaeol. Sci. 32, 1722-1732.

Malaurie, J., 1990. Ultima Thulé. Les Inuits nord-groenlandais face aux conquérants du Pôle (1818-1993). Plon (Collection Terre humaine), Paris.

Mallye, J.-B., 2011. Réflexion sur le dépouillement des petits carnivores en contexte archéologique: apport de l'expérimentation. Archaeofauna 20,7-25.

Marshall, F., 1986. Implications of bone modification in a Neolithic faunal assemblage for the study of early hominid butchery and subsistence practices. J. Hum. Evol. 15, 661-672.

Morin, E., 2007. Fat composition, skeletal part selection, and Nunamiut decision-making. J. Archaeol. Sci. 34, 69-82.

Morin, E., 2012. Reassessing Paleolithic subsistence: the Neandertal and modern human foragers of SaintCésaire. Cambridge University Press, Cambridge.

Morin, E., Ready, E., 2013. Foraging goals and transport decisions in Western Europe during the Paleolithic and early Holocene. In: Clark, J.L., Speth, J.D. (Eds.), Zooarchaeology and modern human origins: Human hunting behavior during the later Pleistocene. Vertebrate Paleobiology and Paleoanthropology Series. Springer, Dordrecht, pp. 227-269.

Nilssen, P.J., 2000. An actualistic butchery study in South Africa and its implications for reconstructing hominid strategies of carcass acquisition and butchery in the upper Pleistocene and Plio-Pleistocene. Ph.D. Dissertation, University of Cape Town.

Odgaard, U., 2007. Historic and prehistoric caribou hunters in West Greenland. Les civilisations du Renne d'hier et d'aujourd'hui. Approches ethnohistoriques, archéologiques et anthropologiques. XXVIIe rencontres internationales d'archéologie et d'histoire d'Antibes.

Olsen, S.L., 1988. The identification of stone and metal tool marks on bone artifacts. In: Olsen, S.L. (Ed.), Scanning electron microscopy in archaeology. Brit. Archaeol. Rep. Int. 452, Oxford, pp. 337-360.

Olsen, S.L., Shipman, P., 1988. Surface modification on bone: trampling versus butchery. J. Archaeol. Sci. 15, 535-553.

Otárola-Castillo, E., 2010. Differences between NISP and MNE in cutmark analysis of highly fragmented faunal assemblages. J. Archaeol. Sci. 37, 1-12.

Padilla Cano, M., 2008. Transmisión cultural y procesos de aprendizaje de carnicería: un estudio experimental comparando expertos y novicios en el descarnado y desarticulación. Arqueoweb 9, 1-76.

Pasda, K., 2013. Caribou hunting and utilization in West Greenland: past and present variants. Anthropozoologica 48, 111-123.

Pasda, K., Odgaard, U., 2011. Nothing is wasted: the ideal "nothing is wasted" and divergence in past and present among caribou hunters in Greenland. Quatern. Int. 238, 35-43.

Potts, R.B., Shipman, P., 1981. Cutmarks made by stone tools on bones from Olduvai Gorge, Tanzania. Nature 291, 577-580.

QGIS Development Team, 2013. QGIS geographic information system. Open Source Geospatial Foundation Project.

Rendu, W., Costamagno, S., Meignen, L., Soulier, M.-C., 2012. Monospecific faunal spectra in Mousterian contexts: implications for social behavior. Quatern. Int. 247, 50-58.

Robert-Lamblin, J., 2007. Influences des paramètres environnementaux et des modes de subsistance sur les modèles culturels des peuples du renne de Sibérie nord-orientale. In: Beyries, S., Vaté, V. (Eds.), Les civilisations du Renne d'hier et d'aujourd'hui. Approches ethnohistoriques et anthropologiques. XXVIIe rencontres internationales d'archéologie et d'histoire d'Antibes. APDCA, Antibes, pp.11-23. 
Roebroeks, W., Verpoorte, A., 2009. A "language-free" explanation for differences between the European Middle and Upper Palaeolithic record. In: Botha, R., Knight, C. (Eds.), The cradle of language. Oxford University Press, Oxford, pp. 146-162.

Roebroeks, W., Kolen, J., Rensink, E., 1988. Planning depth, anticipation and the organization of Middle Palaeolithic technology: the "Archaic Natives" meet Eve's descendants. Helinium 28, 17-34.

Shipman, P., 1986. Scavenging or hunting in early hominids: theoretical framework and tests. Am. Anthropol. $88,27-43$.

Shipman, P., 1988. Actualistic studies of animal resources and hominid activities. In: Olsen, S.L. (Ed.), Scanning electron microscopy in archaeology. Brit. Archaeol. Rep. Int. 452, Oxford, pp. 261-285.

Shipman, P., Rose, J.J., 1983. Early hominid hunting, butchering, and carcass processing behavior: approaches to the fossil record. J. Anthropol. Archaeol. 2, 57-98.

Shipman, P., Rose, J.J., 1984. Cutmark mimics on modern and fossil bovid bones. Curr. Anthropol. 25, 116-117.

Sinclair, H., 1953. The diet of Canadian Indians and Eskimos. Proc. Nutr. Soc. 12, 69-82.

Sokal, R., Rohlf, F., 1969. Biometry: the principles and practice of statistics in biological research. Freeman, San Francisco.

Soulier, M.-C., 2013. Entre alimentaire et technique: l'exploitation animale aux débuts du Paléolithique supérieur. Stratégies de subsistance et chaînes opératoires de traitement du gibier à Isturitz, La Quina aval, Roc-de-Combe et Les Abeilles. Ph.D. Dissertation, Toulouse-Le Mirail University.

Soulier, M.-C., 2014. L'exploitation alimentaire et technique du gibier au début du Paléolithique supérieur aux Abeilles (Haute-Garonne, France). Paleo 25, 287-307.

Soulier, M.-C., Goutas, N., Normand, C., Legrand, A., White, R. 2014. Regards croisés de l'archéozoologue et du technologue sur l'exploitation des ressources animales à l'Aurignacien archaïque: l'exemple d'Isturitz (Pyrénées-Atlantiques, France). In: Jaubert, J., Fourment, N., Depaepe, P. (Eds.), Transitions, ruptures et continuité en Préhistoire, vol. 2. Société Préhistorique française, Paris, pp. 315-332.

Speth, J.D., 2012. Middle Palaeolithic subsistence in the Near East: zooarchaeological perspectives-past, present and future. Before Farming 2, 1-45.

Stefansson, V., 1913. My life with the Eskimo. Kessinger Publishing, Whitefish.

Stefansson, V., 1956. The fat of the land. Macmillan, New York.

Stiner, M.C., Barkai, R., Gopher, A., 2009. Cooperative hunting and meat sharing 400-200 kya at Qesem Cave, Israel. PNAS 106, 13207-13212.

Stopp, M.P., 2002. Ethnohistoric analogues for storage as an adaptive strategy in northeastern subarctic prehistory. J. Anthropol. Archaeol. 21, 301-328.

Thiébaut, C., Costamagno, S., Coumont, M.-P., Mourre, V., Provenzano, N., Théry-Parisot, I., 2010. Approche expérimentale des conséquences du piétinement des grands herbivores sur les vestiges archéologiques. In: Thiébault, C., Coumont, M.-P., Averbouh, A. (Eds.), Mise en commun des approches en taphonomie, Actes du workshop $\mathrm{N}^{\circ} 16-\mathrm{XVe}$ Congrès de l'UISPP, Lisbonne, 2006. Paleo (SI), pp. 109-129.

Thiébaut, C., Claud, E., Costamagno, S., Coudenneau, A., Deschamps, M., Mourre, V., Val, A., Brenet, M., Chacón, M.-G., Chong, S., Coumont, M.-P., Colonge, D., Gerbe, M., Mussini, C., Soulier, M.-C., 2011. Des traces et des hommes: projet de recherche interdisciplinaire sur l'identification des modalités d'acquisition et de traitement des matières végétales et animales au Paléolithique moyen en Europe occidentale. SRA MidiPyrénées report.

Tolmie, C., 2013. Animals for food, animals for tools: fauna as a source of raw material at Abri Cellier, Dordogne, and the Grotte du Renne, Arcy-sur-Cure. Ph.D. Dissertation, University of Iowa.

Turner, E., 2002. Solutré: an archaeozoological analysis of the Magdalenian horizon. Römisch-Germanisches Zentralmuseum, Monographs 46.

Val, A., Mallye, J.-B., 2011. Small carnivore skinning by professionals: skeletal modifications and implications for the European Upper Palaeolithic. Journal of Taphonomy 9, 221-243.

Vallverdú, J., Allué, E., Bischoff, J., Cáceres, I., Carbonell, E., Cebrià, A., García-Anton, D., Huguet, R., Ibáñez, N., Martínez, K., Pastó, I., Rosell, J., Saladié, P., Vaquero, M., 2005. Short human occupations in the Middle Palaeolithic level i of the Abric Romaní rock-shelter (Capellades, Barcelona, Spain). J. Hum. Evol. $48,157-174$.

Vaté, V., Beyries, S., 2007. Une ethnographie du feu chez les éleveurs de rennes du Nord-Est sibérien. Les civilisations du Renne d'hier et d'aujourd'hui. Approches ethnohistoriques, archéologiques et 
anthropologiques. XXVIIe rencontres internationales d'archéologie et d'histoire d'Antibes. APDCA, Antibes, pp.393-419.

Vigne, J.-D., 2005. Découpe du cerf (Cervus elaphus) au Mésolithique moyen, à Noyen-sur-Seine (Seine-etMarne): analyses tracéologique et expérimentale. Revue de Paléobiologie 10, 69-82.

Walker, P.L., 1978. Butchering and stone tool function. Am. Antiq. 43, 710-715.

Walker, P.L., Long, J.C., 1977. An experimental study of the morphological characteristics of tool marks. Am. Antiq. 42, 605-616.

Whallon, R., 1989. Elements of cultural change in the later Paleolithic. In: Mellars, P., Stringer, C. (Eds.), The human revolution. Behavioural and biological perspectives on the origins of modern humans. Princeton University Press, Princeton, pp. 433-454.

Zar, J., 2010. Biostatistical analysis. $5^{\text {th }}$ ed. Prentice Hall, Upper Saddle River. 